\title{
Impact of biometeorological conditions and air pollution on influenza-like illnesses incidence in Warsaw
}

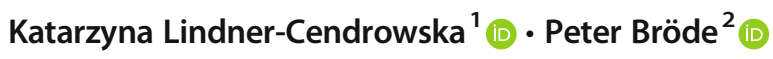

Received: 23 July 2020 / Revised: 4 January 2021 / Accepted: 5 January 2021 / Published online: 17 January 2021

(C) The Author(s) 2021

\begin{abstract}
In order to assess the influence of atmospheric conditions and particulate matter (PM) on the seasonally varying incidence of influenza-like illnesses (ILI) in the capital of Poland-Warsaw, we analysed time series of ILI reported for the about 1.75 million residents in total and for different age groups in 288 approximately weekly periods, covering 6 years 2013-2018. Using Poisson regression, we predicted ILI by the Universal Thermal Climate Index (UTCI) as biometeorological indicator, and by PM2.5 and PM10, respectively, as air quality measures accounting for lagged effects spanning up to 3 weeks. Excess ILI incidence after adjusting for seasonal and annual trends was calculated by fitting generalized additive models. ILI morbidity increased with rising PM concentrations, for both PM2.5 and PM10, and with cooler atmospheric conditions as indicated by decreasing UTCI. While the PM effect focused on the actual reporting period, the atmospheric influence exhibited a more evenly distributed lagged effect pattern over the considered 3-week period. Though ILI incidence adjusted for population size significantly declined with age, age did not significantly modify the effect sizes of both PM and UTCI. These findings contribute to better understanding environmental conditionings of influenza seasonality in a temperate climate. This will be beneficial to forecasting future dynamics of ILI and to planning clinical and public health resources under climate change scenarios.
\end{abstract}

Keywords Influenza $\cdot$ Influenza-like illness $\cdot$ Air quality $\cdot U T C I \cdot$ Seasonality $\cdot$ Biometeorology

\section{Introduction}

Influenza is a seasonal, highly contagious virus that causes periodical epidemics around the world. Each year, an estimated 1 billion cases of influenza is reported, many of which result in severe complications such as pneumonia or even in respiratory deaths (4.0-8.8 fatalities per 100,000 individuals annually) (Iuliano et al. 2018). The virus is known to spread differentially across age groups (Mossong et al. 2008; Huang et al. 2017). Very young children (0-4 years old) and the elderly are reckoned as high-risk groups that suffer from

Katarzyna Lindner-Cendrowska

klindner@twarda.pan.pl

Peter Bröde

broede@ifado.de

1 Institute of Geography and Spatial Organization, Polish Academy of Sciences, Twarda 51/55, 00-818 Warsaw, Poland

2 Leibniz Research Centre for Working Environment and Human Factors at TU Dortmund (IfADo), Dortmund, Germany influenza-related complications most often (Ruf and Knuf 2014; Li et al. 2018). Influenza is transmitted between individuals via direct contact with secretions (by contact with contaminated host or surface) or large droplets (through coughing and sneezing), as well as through airborne transmission (by inhaling small aerosol droplets containing virions that remain suspended in the air) (Shaman and Kohn 2009; Tamerius et al. 2011). The incubation period of influenza is short and ranges from 1 to 4 days (Cox and Subbarao 1999).

Human influenza viruses are divided into three generainfluenza A, B, and C, from which only A and B types cause epidemics in humans (WHO 2020). Thanks to vaccination or as a result of prior infection, population gains immunity to currently spreading strain of virus. However, the influenza virus, espiecially type $\mathrm{A}$, tends to evolve commonlly, using mechanisms like antigenic "drift" or less frequent, but more substantial antigenic "shift" (National Research Council 2001; Nelson and Holmes 2007; Bouvier and Palese 2008). Therefore, vaccinated or recently recovered individuals are usually suscepible to new influenza strains that can emerge in the population (Yaari et al. 2013). Although there are many theoretical and experimental studies on the evolution of 
influenza virus, the timing and properties of new antigenic clusters remain unpredictable (Petrova and Russell 2018).

In temperate climates, influenza morbidity has a clear seasonal pattern. The virus epidemics occur from late autumn to the beginning of spring, with largest peaks in winter (Cox and Subbarao 2000; Heikkinen and Järvinen 2003; Finkelman et al. 2007; Moorthy et al. 2012). These outbreaks are synchronized between regions and countries that have similar climatic conditions (Crépey and Barthélemy 2007; Wenger and Naumova 2010; Schanzer et al. 2011) and usually last from 1 to 4 months (Simonsen 1999). For the rest of the year, influenza stays active at very low level (Lofgren et al. 2007). On the contrary in tropical and subtropical climatic zones, temporal patterns of virus activity are more complex and frequently associated with rain season (de Arruda et al. 1991; Moura et al. 2009). Many hot and humid regions experience two distinct epidemical seasons within the year: in winter and summer/autumn (Chan et al. 2009; Tamerius et al. 2011; Wang et al. 2017). Although influenza incidence exhibits strong seasonality, the magnitude and timing of its outbreaks change from year to year even within one population (Huppert et al. 2012; Moorthy et al. 2012; Yaari et al. 2013).

There is no single recognized main driver of influenza seasonality (Shaw Stewart 2016); however, three mechanisms may explain viral seasonality in temperate climate (Lipsitch and Viboud 2009; Tamerius et al. 2011; Pica and Bouvier 2012), as described in detail below:

1 Seasonal variations in host contact rate: With decreasing ambient temperature in winter, people spend more time crowding indoors, which favours greater disease transmission (Lofgren et al. 2007; Fisman 2012). However, studies in mice indicated that even under identical crowding conditions, flu transmission demonstrates a clear seasonal pattern (Schulman and Kilbourne 1963). Thus, temperaturedependent changes in host contact rates are not the main factor, but rather contribute to the seasonal incidence of influenza by amplifying transmission among population (Lofgren et al. 2007; Shaw Stewart 2016).

2 Virus survival capability and effectiveness of transmission: Thermal conditions have also important impact on the survival of influenza virus. In colder environment, the integrity of viral envelope is better, whereas at higher air temperature, above $21^{\circ} \mathrm{C}$, the envelope becomes disordered, leading to higher virus susceptibility to damage (Polozov et al. 2008). With seasonal rise of air temperature, virions can stay dormant in lower parts of human respiratory tract until late autumn and winter, when sudden chilling of inhaled air frequently occurs, which activates dormant viruses and starts an infection as a result (Shaw Stewart 2016). Seasonally changing influenza virulence is also dependent on its possibility to survive outside human body and to transmit effectively from one host to another. The most sensitive to atmospheric conditions is airborne transmission (Lowen et al. 2007). At low relative humidity (RH$20-35 \%)$, large droplets, expelled during coughing or sneezing, evaporate quickly, leading to creation of smaller and lighter droplets that are more likely to remain suspended in the air for an extended period of time (Schaffer et al. 1976; Tellier 2006; Weber and Stilianakis 2008). Therefore airborne transmission of influenza is the most efficient in cold dry air (Weinstein et al. 2003; Lowen and Steel 2014; Gustin et al. 2015).

3 Fitness of the host immune system: There is a substantial evidence that seasonal variations of influenza incidence may be the effect of cyclically changing host immunity to respiratory tract illnesses (Dowell 2001). Human susceptibility to viral infections changes with photoperiod variations (Lofgren et al. 2007). In wintertime, due to deficiency of UV radiation, a lower vitamin D production in the organism is observed, which results in immune suppression and lower ability to fight infections (Cannell et al. 2006; Ginde et al. 2009; Urashima et al. 2010; Martineau et al. 2017). Increased host susceptibility to viruses is also linked to seasonal decrease of air temperature. Inhaling cold air and excess cooling of the body surface can induce cold stress that leads to pathophysiological responses of human organism that compromise immune system (Mourtzoukou and Falagas 2007). Breathing dry and cold air may cause constriction of the blood vessels of the upper airways, as well as desiccation of nasal mucosa and reduction of mucociliary clearance, all of which result in increased susceptibility to infection (Salah et al. 1988; Eccles 2002). Moreover, excessive chilling increases energy demand for thermoregulation that limits energy available for immune defence and leaves human organism vulnerable to pathogens (Lochmiller and Deerenberg 2000; Lofgren et al. 2007; Jaakkola et al. 2014).

Although local meteorological factors clearly affect transmission of virus infections (Fdez-Arroyabe 2012; Price et al. 2019), our understanding of the role of specific climatic determinants in influenza epidemiology is very limited and many uncertainties still remain (Pica and Bouvier 2012). There is a general agreement that high sun activity (especially intensive UV radiation) inactivates enveloped viruses (Jensen 1964; Sagripanti and Lytle 2007). Mean air temperature is also an important factor affecting influenza epidemics in temperate climate (du Prel et al. 2009; Sundell et al. 2016). Viral infectivity and persistence are higher in colder environments (Lofgren et al. 2007; Lowen et al. 2007), while laboratory tests confirm that at temperature above $30{ }^{\circ} \mathrm{C}$, influenza transmission in aerosol stops completely (Lowen et al. 2008). However, a study from Northern Finland demonstrates that 
the risk of infection paradoxically can decrease also at very low air temperature (Jaakkola et al. 2014). Furthermore, Shaw Steward (2016) and Li et al. (2018) argued that it is not absolute temperature value, but rather diurnal temperature variations that are responsible for higher acute respiratory tract infections incidence. There are inconclusive results about the potential impact of air humidity on influenza morbidity. Numerous studies confirmed that low content of water vapour in the air increases the transmission and survival of aerosolized influenza virions (Tellier 2006; Brankston et al. 2007; Lowen et al. 2007). Conversely, other studies indicate that higher influenza activity is rather associated with high relative humidity (Chan et al. 2009; Li et al. 2018). On the other hand, Tang et al. (2010) and Iha et al. (2016) emphasize that depending on the influenza type (A or B) and geographical location, the correlation between infection rate and RH may be positive or negative. However, some researchers (Shaman and Kohn 2009; McDevitt et al. 2010; Pica and Bouvier 2012) suggest that high survival and transmission rates of influenza show stronger association with absolute humidity (AH). Low AH values highly correlate with the onset of influenza epidemics in USA (Shaman et al. 2010) and Japan (Shoji et al. 2011). Less attention has been paid to the effects of other meteorological factors on influenza incidence so far. Several previous studies showed low wind speed contributing to virus spread (Schulman and Kilbourne 1963; Xiao et al. 2013; Roussel et al. 2016). Precipitation has been reckoned to be insignificant as influenza predictor (Tang et al. 2010) or otherwise was associated with respiratory tract infections morbidity, especially in the tropics (Chan et al. 2002; Robertson et al. 2004; Agrawal et al. 2009; Gomez-Barroso et al. 2017).

There is also some evidence that poor air quality can be a significant risk factor for lower respiratory tract infections. Exposure to atmospheric pollution leads to irritation and mechanical damage of airway mucosa, due to generation of free radicals, compromising mucociliary clearance and diminishing individual resistance to viral infections (Ciencewicki and Jaspers 2007; Fuhrmann 2010). Moreover, laboratory tests indicated that transport pollutants (precisely diesel exhaust) increase the ability of influenza virus to attach and enter to respiratory epithelial cells (Jaspers et al. 2005). Specifically, particulate matter is frequently associated with higher morbidity due to respiratory infections (Hwang and Chan 2002; Chen et al. 2017). PM10 contributes to the transmission of influenza by providing condensation nuclei to which virus droplets can attach and therefore remain suspended in the air for time long enough to be inhaled by a susceptible individual (Hammond et al. 1989; Lee et al. 2014; Feng et al. 2016).

Determining the presence of the influenza virus in the population, by performing laboratory tests, is costly, thus performed occasionally by random sampling on symptomatic patients, in order to determine current circulating strains
(Meerhoff et al. 2004). Furthermore, influenza can be difficult to diagnose basing on clinical symptoms alone, as various other viruses and bacteria can cause similar health ailments (Heikkinen and Järvinen 2003; Eccles 2005; Liu et al. 2019), and only $5-15 \%$ of common colds is induced by influenza virus (Zambon et al. 2001). Alternatively, a common respiratory syndrome, called influenza-like illness (ILI), frequently serves as influenza-proxy in epidemiological studies (Mandl et al. 2004; Minh An et al. 2014; Silva et al. 2014; Su et al. 2019). Although the commonly weekly reported number of ILI cannot exactly correspond to real influenza morbidity, it can generally represent the influenza activity in the population (Wang et al. 2017). Recent studies have shown that laboratory confirmed influenza cases were highly correlated with ILI rates (Yaari et al. 2013). In addition, applying a weekly time-scale enables overcoming the problem of under representativeness of ILI cases during weekends and public holidays, due to limited accessibility to healthcare institutions (Buckingham-Jeffery et al. 2017). This approach also compensates for the increased daily admissions on the first labour day after the break, described earlier as "the Monday effect" (Romaszko et al. 2019).

Although many previous studies have recognized the significance of meteorological parameters on the transmission and influenza morbidity, the results differ regionally and are strongly affected by the climate type and social structure. In Poland, the association between weather variables and viral infections was so far analysed in detail only in relation to general respiratory tract diseases (Romaszko et al. 2019).

Therefore, the aim of the current study is to determine whether seasonal variability of influenza-like illnesses is affected by atmospheric conditions and air quality in the capital of Poland-Warsaw.

\section{Materials and methods}

Warsaw, with a population of 1.78 million (Statistics Poland 2020), is situated in the central part of the country, on the Masovian Plain. It is characterized by humid continental climate (Dfb type), with cold, cloudy winter, and warm summer (Peel et al. 2007), which is modified by the Urban Heat Island effect (Błażejczyk et al. 2014). Mean monthly temperature fluctuates in Warsaw from $-1.9^{\circ} \mathrm{C}$ in January to $19.0^{\circ} \mathrm{C}$ in July, while yearly rainfall total is $531.5 \mathrm{~mm}$ (Institute of Meteorology and Water Management 2020).

\section{Epidemiological data}

Data on influenza incidence was provided by the Voivodship Unit of the State Sanitary Inspection in Warsaw. Polish medical centres report to the State Sanitary Inspection weekly rates of ILI incidence, based on a clinical case definition. ILI cases 
are defined as sudden onset of at least one general symptom (fever or subfebrile condition, malaise, headache, muscle pain) followed by at least one of the respiratory symptoms (cough, sore throat, dyspnoea) (Department of Infectious Disease Epidemiology and Surveillance NIZP-PZH 2019). This definition is in general consistent with $\mathrm{J} 10$ and $\mathrm{J} 11$ codes in ICD-10 classification.

It is important to notice that reporting periods in Polish surveillance system are not always 7-day periods, i.e. 1 week exactly. In each month, first and third period consist of 7 days, the second one is 8 days long, while the forth reporting period varies from 6 to 9 days. Thus, the time series consisted of 4 periods per month, 48 periods per year, and 288 periods covering 6 years from 1 January 2013 to 31 December 2018. To overcome the unbalanced number of days per period, mean daily ILI incidence (dILI) was calculated, dividing total amount of ILI cases by the number of days for each reporting period, while adjusting to population size (cf. below). Influenza incidence reports in Poland do not comprise any personal information, like gender or accompanying chronic diseases, but total ILI cases are subdivided into four age groups: 0-4 (infants and young children), 5-14 (school children), 15-64 (youngsters and adults), and above 64 years old (elderly).

To account for changing population size, yearly data on the number of Warsaw residents corresponding to the observation period (2013-2018) and to the four age groups were obtained from Local Data Bank of Polish Central Statistical Office (Statistics Poland 2020).

\section{Meteorological and air quality data}

In order to characterize typical meteorological conditions in Warsaw (Poland), meteorological data from Warsaw-Bielany weather station $(52.17 \mathrm{~N}, 20.58 \mathrm{E}, 98 \mathrm{~m}$ a.s.l.) was obtained from the Institute of Meteorology and Water Management in Warsaw (IMGW), Poland. This weather station was selected due to high completeness of the data set and its representativeness for the bioclimate of the build-up areas within the city. Hourly air temperature $\left(t,{ }^{\circ} \mathrm{C}\right)$, vapour pressure $(v p$, $\mathrm{hPa})$, relative humidity $(R H, \%)$, wind speed $(v, \mathrm{~m} / \mathrm{s})$ and cloudiness ( $N$, octas), were collected from the period of analysis, i.e. 2013-2018.

Thermal stress causes significant load on human organism and increases energy demand for thermoregulation at the expense of energy available for immune defence, which may result in higher susceptibility to infections (Lochmiller and Deerenberg 2000). To assess biothermal environment and degree of thermal stress in men, the Universal Thermal Climate Index (UTCI) was applied. UTCI is defined as an equivalent ambient temperature $\left({ }^{\circ} \mathrm{C}\right)$ of a reference environment, causing the same physiological response of a reference human organism as the actual environment (Błażejczyk et al. 2013). Hourly values of UTCI were calculated in BIOKLIMA 2.6 software (Błażejczyk 2005). In order to obtain UTCI values, the software calculates mean radiant temperature $\left(\right.$ tmrt,$\left.{ }^{\circ} \mathrm{C}\right)$, using following formula (Eq. 1):

tmrt $=\left(\frac{\frac{R}{\operatorname{Irc}}+0.5 \cdot L g+0.5 \cdot L a}{s_{h} \cdot \sigma}\right)^{0.25}-273$

where $R$ is the absorbed solar radiation $\left(\mathrm{W} / \mathrm{m}^{2}\right), \operatorname{Irc}$ is the coefficient reducing convective and radiative heat transfer through clothing, $L g$ is the ground radiation $\left(\mathrm{W} / \mathrm{m}^{2}\right), L a$ is the atmosphere outgoing radiation $\left(\mathrm{W} / \mathrm{m}^{2}\right), \mathrm{s}_{\mathrm{h}}$ is the emissivity coefficient for humans (0.95), and $\sigma$ is the Stefan-Boltzmann constant $\left(5.667 / 10^{8} \mathrm{~W} / \mathrm{m}^{2} \cdot \mathrm{K}^{4}\right)$. Absorbed solar radiation $(R)$ was calculated from cloudiness $(N)$ using the SolAlt model provided by BIOKLIMA. Detailed formulas are available online in Electronic Supplemental Note 1.

Hourly means of PM2.5 and PM10 concentration were obtained from the one of the Chief Inspectorate of Environmental Protection (GIOŚ) air quality monitoring points-Warszawa-Ursynów (52.16 N, 21.03 E, $102 \mathrm{~m}$ a.s.l.). Air pollution data originated only from the one place within Warsaw agglomeration, as it was the only station that recorded detailed measurements of PM2.5 and PM10 over a long enough period of time.

All meteorological and air pollution data, as well as biometeorological indices, were averaged and aligned to the ILI reporting periods.

\section{Statistical analysis}

Descriptive statistical analyses were conducted to describe the nature of weekly rates of medical consultations due to influenza-like illnesses, as well as meteorological and aerosanitary data. Considering the potential non-Gaussianity of both meteorological variables and air pollutants data, Spearman correlation was used to illustrate the association between ILI and particular weather parameters and the air pollutants.

Following a recently described modelling framework (Bhaskaran et al. 2013), we analysed the influence of UTCI and PM2.5, as well as UTCI and PM10, respectively, on excess ILI incidence, i.e. after adjusting for seasonal and longterm trends. We applied Poisson regression models allowing for over-dispersion separately to the time series for the different age groups as well as for the total numbers (Fig. 1).

Fitting generalized additive models (GAM), the log ILI counts at period $t(t=1, \ldots, 288)$ were predicted in separate models according to Eq. 2 by linear terms for either PM2.5 or PM10 as indicators of aerosanitary conditions, adjusting for the biometeorological influence represented by UTCI. In addition, penalized cubic regression splines (Wood 2006) were included as predictors of the seasonal cycle within a year 

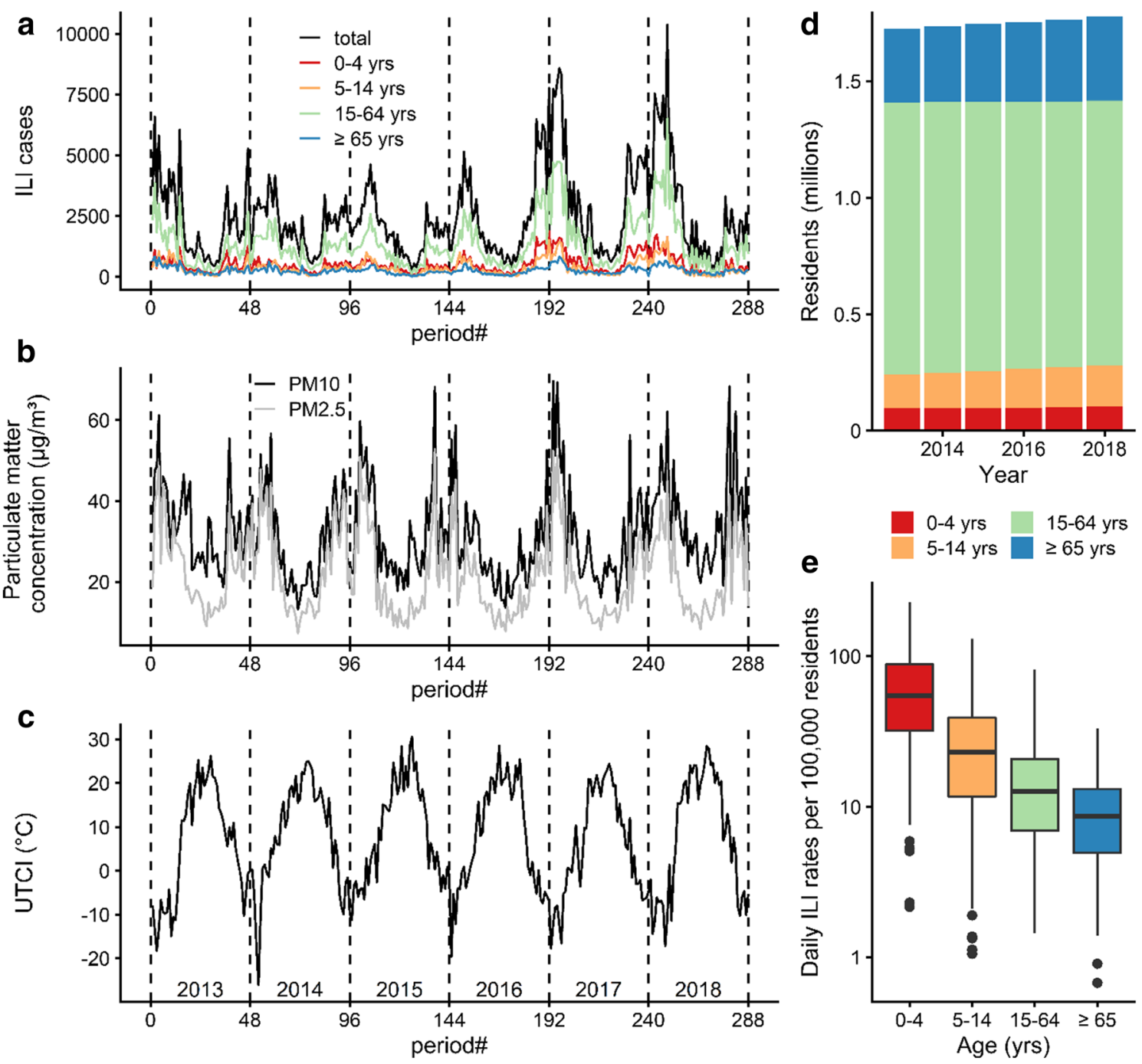

Fig. 1 Time series of ILI cases in total and in different age strata (a), of PM2.5 and PM10 (b), and of UTCI (c) over the 288 reporting periods covering the time segment from 01 January 2013 to 31 December 2018

$\left(f_{\text {seas }}\right)$ and the long-term annual trend $\left(f_{\text {long }}\right)$, respectively. Specifically, using the notation introduced by Wood (2006), $f_{\text {long }}$ refers to a natural cubic regression spline with basis dimension set to $k=9$ (i.e. with $k-1=8$ as upper limit of the associated degrees of freedom). Similarly, $f_{\text {seas }}$ represents a cyclic cubic regression spline with $k=12$ applied to the period-within-year calculated as $t \bmod 48+1$.

$$
\begin{aligned}
\log \left(I L I_{t}\right)= & \text { intercept }+\alpha \text { UTCI }_{t}+\beta \text { PM }_{t} \\
& +f_{\text {seas }}(t \bmod 48+1)+f_{\text {long }}(t) \\
& +\gamma_{\equiv 1} \log \left(p t_{t}\right)
\end{aligned}
$$

In order to consider the varying population size and lengths of the reporting periods, ILI counts were analysed as rates, i.e. as daily ILI per unit population size. This was achieved by including the log product of population size multiplied with with dashed vertical lines indicating the end of the reporting year. Annual development of Warsaw population stratified by age (d), and log-scaled distribution of daily ILI rates per 100,000 residents related to age (e)

days within the reporting period $(p t)$, as offset with coefficient $\gamma_{\equiv 1}$ fixed to one. This approach is a commonly applied statistical technique to treat such data within the Poisson regression framework (Dunn and Smyth 2018). Thus, the estimated coefficients $\alpha$ of $U T C I$ and $\beta$ of PM2.5 or PM10 in Eq. 2 represent $\log$ rate ratios (RR), from which we calculated the percentage change in daily ILI incidence rate per unit increase in UTCI or $P M$, respectively, as \%change $=(\mathrm{RR}-1) \cdot 100$.

In previous studies, 7 to 14 days delay between weather change and increase in respiratory tract infections incidence has been observed (Nastos and Matzarakis 2006; Mäkinen et al. 2009; Sundell et al. 2016). To investigate the lag effect between particular biometeorological and aerosanitary conditions and ILI incidence in Warsaw, we considered values of UTCI, PM2.5, and PM10 lagged by one and two reporting periods in addition to the actual value (lag 0). Following the approach suggested by Bhaskaran et al. (2013), we fitted 
individual lag models, i.e. separate models including as predictors the different lagged $(0,1$, and 2 periods) values of UTCI, PM2.5, and PM10, as well as the averaged lagged values, respectively.

We compared these models to a distributed lag model (Eq. 3) considering all lagged values simultaneously, from which we calculated the cumulative or "net" effect over all lags as the sum of the coefficients of the different lagged exposures (Bhaskaran et al. 2013).

$$
\begin{aligned}
\log \left(I L I_{t}\right)= & \text { intercept }+\sum_{l=0}^{2} \alpha_{l} U T C I_{t-l}+\sum_{l=0}^{2} \beta_{l} P M_{t-l} \\
& +f_{\text {seas }}(t \bmod 48+1)+f_{\text {long }}(t) \\
& +\gamma_{\equiv 1} \log \left(p t_{t}\right)
\end{aligned}
$$

In order to investigate the interaction of age with the effects of PM2.5, PM10 and UTCI on excess ILI incidence after adjusting for seasonal and long-term trends, respectively, we additionally performed the above described analysis with the averaged lagged values as predictors after combining the series of the four groups and introducing age as additional factor in Eq. 2 (Wood 2006).

The calculations were carried out with version 3.6.3 of the $\mathrm{R}$ software (R Core Team 2020) using packages mgcv (Wood 2006), mgcViz (Fasiolo et al. 2020), and emmeans (Lenth 2020).

\section{Results}

A total of 713,399 ILI cases were reported in Warsaw from January 2013 to December 2018. The descriptive statistics for meteorological and air pollution weekly data and mean daily ILI morbidity rates (total and in different age groups) per 100,000 residents were summarized in Table 1 . The mean ILI morbidity per 100,000 residents was 18.8 per day, with the maximum of 83.3 from 1 to 7 March 2018. During the study period, meteorological conditions were typical for the Dfb (cold with warm summer) Köppen climate zone (Peel et al. 2007). Mean weekly UTCI values varied from $-26.0^{\circ} \mathrm{C}$ in January 2014 to $30.5^{\circ} \mathrm{C}$ in August 2015, what corresponds to UTCI categories from strong cold stress to moderate heat stress. The PM2.5 and PM10 daily concentrations varied seasonally and reached maximum values usually in the cold season (Fig.1b), as air pollution in Poland is mainly related to residential heating systems (Adamczyk et al. 2017) using individual, coal-fired heating stoves.

The time series of ILI counts (Fig. 1a) exhibited a seasonal pattern with maximum values during winter and minimum numbers during summer, as well as demonstrated annual differences with the highest daily ILI rates in 2018 and 2017, respectively. This periodicity was observed for the total sample as well as for the different age groups. While the seasonal ILI pattern was similar to the course of PM2.5 and PM10 (Fig. 1b), it was inversely related to UTCI (Fig. 1c). The highest ILI counts were observed for people 15-64 years of age (Fig. 1a), who form the majority of Warsaw residents (Fig. 1d). When standardized for population size (Fig. 1e), daily ILI incidence rate showed a decreasing trend with age.

Total daily influenza-like illnesses ( $(I L I)$ rates were significantly correlated with all analysed atmospheric variables (Tab. 2). The strongest negative correlation was between $d I L I$ and vapour pressure $(v p)$ or air temperature $(t)$ (both
Table 1 Descriptive statistics for weekly atmospheric data and influenza-like illness (total and in

\begin{tabular}{|c|c|c|c|c|c|c|}
\hline \multirow[t]{2}{*}{ Variables } & \multirow[t]{2}{*}{ Mean \pm SD } & \multirow[t]{2}{*}{ Min } & \multicolumn{3}{|c|}{ Percentile } & \multirow[t]{2}{*}{ Max } \\
\hline & & & 25 & 50 & 75 & \\
\hline \multicolumn{7}{|l|}{ Atmospheric data } \\
\hline Air temperature $t\left({ }^{\circ} \mathrm{C}\right)$ & $10.7 \pm 8.6$ & -10.7 & 3.5 & 10.7 & 18.4 & 28.2 \\
\hline Relative humidity $R H(\%)$ & $72.3 \pm 12.6$ & 36.8 & 62.6 & 72.3 & 83.1 & 93.9 \\
\hline Vapour pressure $v p(\mathrm{hPa})$ & $9.9 \pm 4.2$ & 1.9 & 6.4 & 9.4 & 13.4 & 21.1 \\
\hline Wind speed $v(\mathrm{~m} / \mathrm{s})$ & $2.4 \pm 0.6$ & 1.2 & 1.9 & 2.3 & 2.8 & 4.2 \\
\hline Mean radiant temperature $\operatorname{tmrt}\left({ }^{\circ} \mathrm{C}\right)$ & $11.5 \pm 14.4$ & -18.7 & -1.4 & 11.4 & 24.4 & 39.8 \\
\hline$U T C I\left({ }^{\circ} \mathrm{C}\right)$ & $7.4 \pm 12.3$ & -26.0 & -3.1 & 7.7 & 18.4 & 30.5 \\
\hline PM2.5 $\left(\mu \mathrm{g} / \mathrm{m}^{3}\right)$ & $21.8 \pm 10.4$ & 7.4 & 13.4 & 18.9 & 28.6 & 52.8 \\
\hline $\operatorname{PM} 10\left(\mu \mathrm{g} / \mathrm{m}^{3}\right)$ & $31.6 \pm 11.5$ & 13.2 & 23.1 & 29.0 & 38.5 & 69.7 \\
\hline \multicolumn{7}{|c|}{ Daily influenza-like illness ( $d I L I)$ per 100,000 residents } \\
\hline $0-4$ years old & $67.9 \pm 49.7$ & 2.2 & 31.9 & 54.9 & 88.5 & 228.5 \\
\hline $5-14$ years old & $29.7 \pm 24.6$ & 1.1 & 11.7 & 22.9 & 39.0 & 130.4 \\
\hline 15-64 years old & $15.8 \pm 12.3$ & 1.4 & 7.0 & 12.6 & 20.8 & 81.9 \\
\hline 65 years old and above & $9.9 \pm 6.3$ & 0.7 & 4.9 & 8.6 & 13.1 & 33.3 \\
\hline Total & $18.8 \pm 13.8$ & 1.6 & 9.0 & 15.3 & 24.9 & 83.3 \\
\hline
\end{tabular}
age groups) from 288 reporting periods in Warsaw (2013-2018)
Note: $S D$ standard deviation 
Table 2 Spearman correlation coefficients between $d I L I$ per 100,000 residents and atmospheric parameters from 288 reporting periods in Warsaw (2013-2018)

\begin{tabular}{|c|c|c|c|c|c|c|c|c|c|c|c|c|}
\hline & \multicolumn{5}{|l|}{$d I L I$} & \multirow[t]{2}{*}{$t$} & \multirow[t]{2}{*}{$R H$} & \multirow[t]{2}{*}{$v p$} & \multirow[t]{2}{*}{$v$} & \multirow[t]{2}{*}{ tmrt } & \multirow[t]{2}{*}{ UTCI } & \multirow[t]{2}{*}{ PM2.5 } \\
\hline & Total & $\begin{array}{l}0 \\
4 \text { years }\end{array}$ & $\begin{array}{l}5- \\
14 \text { years }\end{array}$ & $\begin{array}{l}15- \\
64 \text { years }\end{array}$ & $\geq 65$ years & & & & & & & \\
\hline$t$ & $-0.73 * *$ & $-0.68 * *$ & $-0.74 * *$ & $-0.71 * *$ & $-0.68 * *$ & & & & & & & \\
\hline$R H$ & $0.44 * *$ & $0.44 * *$ & $0.44 * *$ & $0.43 * *$ & $0.43 * *$ & $-0.69 * *$ & & & & & & \\
\hline$v p$ & $-0.73 * *$ & $-0.67 * *$ & $-0.74 * *$ & $-0.72 * *$ & $-0.67 * *$ & $0.95 * *$ & $-0.45^{* *}$ & & & & & \\
\hline$v$ & $0.35 * *$ & $0.32 * *$ & $0.29 * *$ & $0.36^{* *}$ & $0.35^{* *}$ & $-0.39 * *$ & $0.24 * *$ & $-0.37 * *$ & & & & \\
\hline tmrt & $-0.69 * *$ & $-0.65^{* *}$ & $-0.70^{* *}$ & $-0.67 * *$ & $-0.64 * *$ & $0.98 * *$ & $-0.76^{* *}$ & $0.90^{* * *}$ & $-0.37 * *$ & & & \\
\hline UTCI & $-0.72 * *$ & $-0.68 * *$ & $-0.73 * *$ & $-0.71 * *$ & $-0.67 * *$ & $0.99 * *$ & $-0.69 * *$ & $0.93 * *$ & $-0.49 * *$ & $0.98 * *$ & & \\
\hline PM2.5 & $0.67 * *$ & $0.60 * *$ & $0.66^{* *}$ & $0.66^{* *}$ & $0.67 * *$ & $-0.77 * *$ & $0.57 * *$ & $-0.73 * *$ & $0.11^{* *}$ & $-0.76^{* *}$ & $-0.74 * *$ & \\
\hline PM10 & $0.54 * *$ & $0.47 * *$ & $0.51 * *$ & $0.54 * *$ & $0.56^{* *}$ & $-0.54 * *$ & $0.32 * *$ & $-0.56^{* *}$ & $0.04 * *$ & $-0.50 * *$ & $-0.50 * *$ & $0.88 * *$ \\
\hline
\end{tabular}

Note: ${ }^{* *} p<0.0001,{ }^{*} p<0.05$, all abbreviations are explained in Table 1

$-0.73)$, but also UTCI $(-0.72)$. Moderate strong positive associations were observed between $d I L I$ and particulate matter (0.67 for PM2.5 and 0.54 for PM10). Furthermore, air pollution concentration (especially PM2.5) was strongly negatively correlated with $t$, mean radiant temperature (tmrt), UTCI, and $v p$. Correlations between $d I L I$ and meteorological elements (with the exception of $v$ ) were the strongest for children 5-14 years, while the strongest relationship between dILI and particulate matter was observed for elderly people ( $\geq 65$ years).

Figure 2 summarizes the results from the Poisson regression analyses performed for the time series of total daily ILI incidence rates with the trend function fitted by GAM (Fig. 2a). A cyclical seasonal component, showing a minimum in summer and a maximum for late winter (Fig. 2b), and annual fluctuations with increased rates in 2017 and 2018 and lower rates during the final year (Fig. 2c) were detected. After adjusting for general trend, the individual lag models indicated rising ILI rates per unit increase in PM2.5 or PM10 and per unit decrease in UTCI, respectively (Fig. 2d). Both PM2.5 and PM10 effects were statistically significant for the current period (lag 0 ) value and declined at higher lags. In turn, for UTCI, the estimates were less differentiated over the three lag periods, with the greatest, statistically significant effect at one-period-lagged values (Tab. S1 in the Electronic Supplemental Material ESM). The overall effect on ILI incidence, represented by the averaged single lag values of PM2.5 and UTCI, demonstrated that estimated ILI rate changes were $1.2 \%$ per $1 \mu \mathrm{g} / \mathrm{m}^{3}$ increase in PM2.5 and $1.9 \%$ per $1{ }^{\circ} \mathrm{C}$ decrease in UTCI (Fig. 2d). For the overall effect of PM10 and UTCI, the estimated ILI rate changes were $1.2 \%$ per $1 \mu \mathrm{g} / \mathrm{m}^{3}$ increase and $2.2 \%$ per $1{ }^{\circ} \mathrm{C}$ decrease, respectively. In order to demonstrate the cumulative effect of an exposure to air pollution and particular biothermal conditions over all three periods (for 0,1 , and 2 lag together), the unconstrained distributed lag model simultaneously considered all lagged variables as predictors (Fig. 2e). This model corroborated the results for individual models, although the estimates for the lagged effects were slightly reduced and statistically non-significant for UTCI. The smaller magnitudes of the effects and wider confidence intervals in the distributed model were presumably a result of the multi-collinearity between the lagged predictor values. The cumulative net effects, calculated from the summed coefficients of the lagged exposures (Fig. 2e), were almost identical to the effects from the individual model using the averaged lagged values as predictors (Fig. 2d). Accordingly, the estimated ILI rates also increased $1.2 \%$ per $1 \mu \mathrm{g} / \mathrm{m}^{3}$ increase in PM2.5 and PM10 concentrations, but were a bit smaller for $1{ }^{\circ} \mathrm{C}$ decrease in UTCI values $(-1.7$ and $2.0 \%$, respectively) (Tab. S2 in ESM).

We performed a sensitivity analysis to verify the linear Poisson regression approach by replacing the linear terms for $U T C I$ and $P M$ in Eq. 2 with penalized tensor-product splines with basis dimension set to $k=5$ (Wood 2006) allowing for potential nonlinear relationships of excess ILI incidence with air pollution and meteorological influences after adjusting for seasonal and long-term annual trends. However, the corresponding results, e.g. as shown in Fig. S1 in ESM for the averaged lagged effects of UTCI and PM10 exhibited a linear relationship, thus corroborating the appropriateness of the linear Poisson regression approach in Eq. 2. Moreover, including a further two-dimensional tensor product spline with basis dimension $k=5^{2}=25$ representing the interaction between UTCI and air pollution did not improve the predictive model significantly, as indicated by the corresponding non-significant likelihood ratio test results for UTCI in combination with PM2.5 $(p=0.60)$ and PM10 $(p=0.11)$, respectively. Thus, the main effects linear Poisson regression model adequately fitted our data concerning the influence of air pollution and biometeorological conditions on excess ILI incidence. 


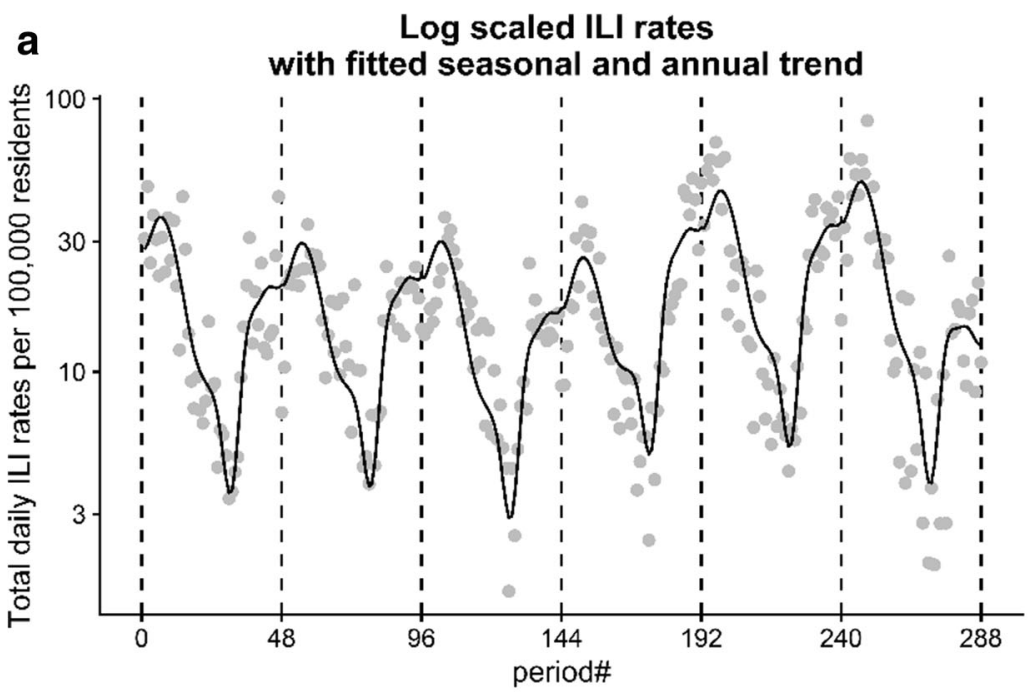

d

\%change in ILI rate per unit increase from individual lag models
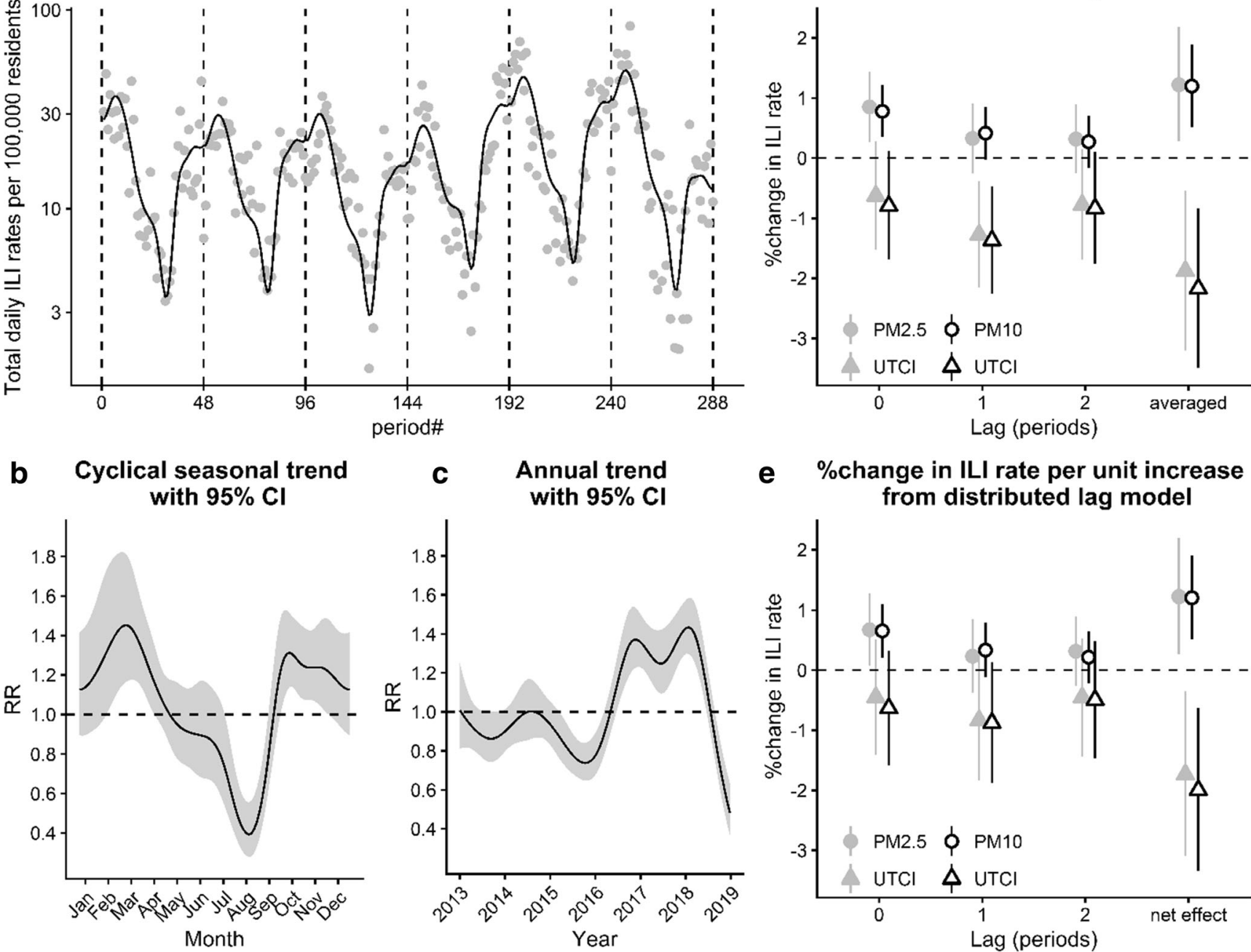

e \%change in ILI rate per unit increase
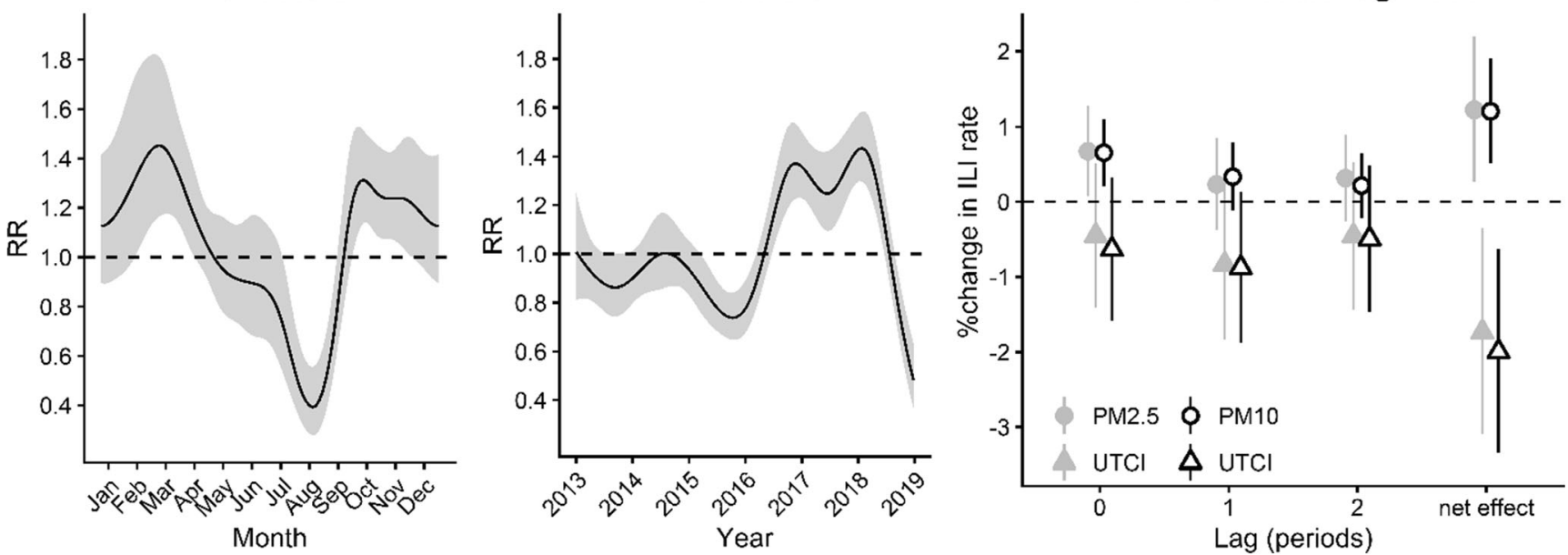

Fig. 2 Total daily ILI rates on a log scale with dashed vertical lines indicating the end of the reporting year (a), with spline functions fitted by generalized additive models (GAM) to seasonal (b) and annual trends (c) expressed as rate ratios (RR) relative to the overall mean. Percentage change in ILI rates per unit increase in the predictors from Poisson

regression models individually considering different lagged and the averaged lagged values of UTCI together with PM2.5 (grey symbols) or PM10 (black open symbols), respectively, (d), as well as distributed lagged and cumulated net effects (e). Error bands and bars indicate 95\% confidence intervals $(\mathrm{CI})$

Regarding the influence of PM2.5 or PM10 and UTCI on ILI incidence for different age groups, the corresponding results after applying the models in Eqs. 2 and 3 were similar to those from the total counts, with the exception for the youngest age group ( $0-4$ years) (Tab. S1 and Tab. S2). For young children, the estimates were smaller, and both averaged and net effects for PM2.5 or PM10 and UTCI were non-significant. The strongest effects of air pollution and biothermal conditions on ILI rates with the narrowest confidence intervals were observed for people 15-64 years, which can be attributed to the increased statistical power for this group (Armstrong et al. 2020) with the highest raw counts in the greatest subpopulation (Fig. 1a and d).

Subsequently, the potential moderating influence of age on seasonal and annual trends, along with ILI incidence rate changes, was investigated. Figure 3 addresses the effects of the averaged lagged values of PM2.5 or PM10, respectively, combined with UTCI, and estimated from the pooled series of ILI counts for the four age groups. The seasonal (Fig. 3a) and annual trends (Fig. 3b) were alike those for the total series (Fig. 2), except for the oldest people ( $\geq 65$ years), who showed less pronounced seasonal and long-term morbidity trends, compared to the other age groups. There was a statistically significant main effect with ILI rates decreasing with age, with post hoc tests indicating that all group differences, except that between the two oldest groups, were significant (Fig. 3c). The main overall effects of PM2.5 and UTCI or PM10 and UTCI (Fig. 3d) were significant and similar in size to the previous analyses (Fig. 2). Although, the estimated effects for young children ( $0-4$ years) were smaller, compared to the other 


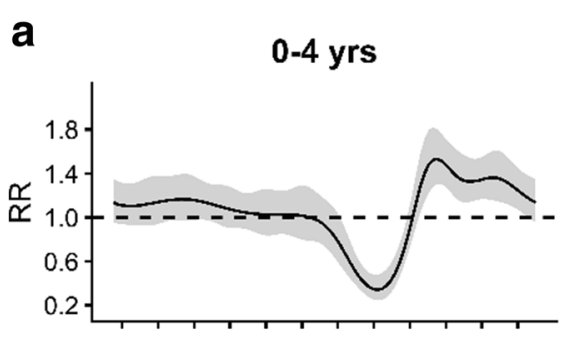

5-14 yrs

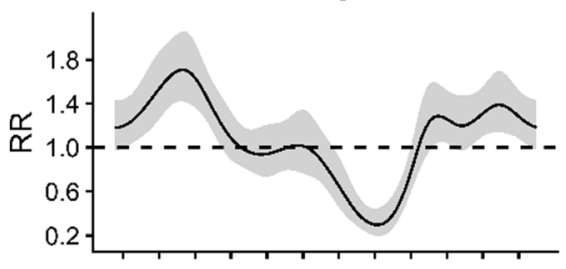

15-64 yrs
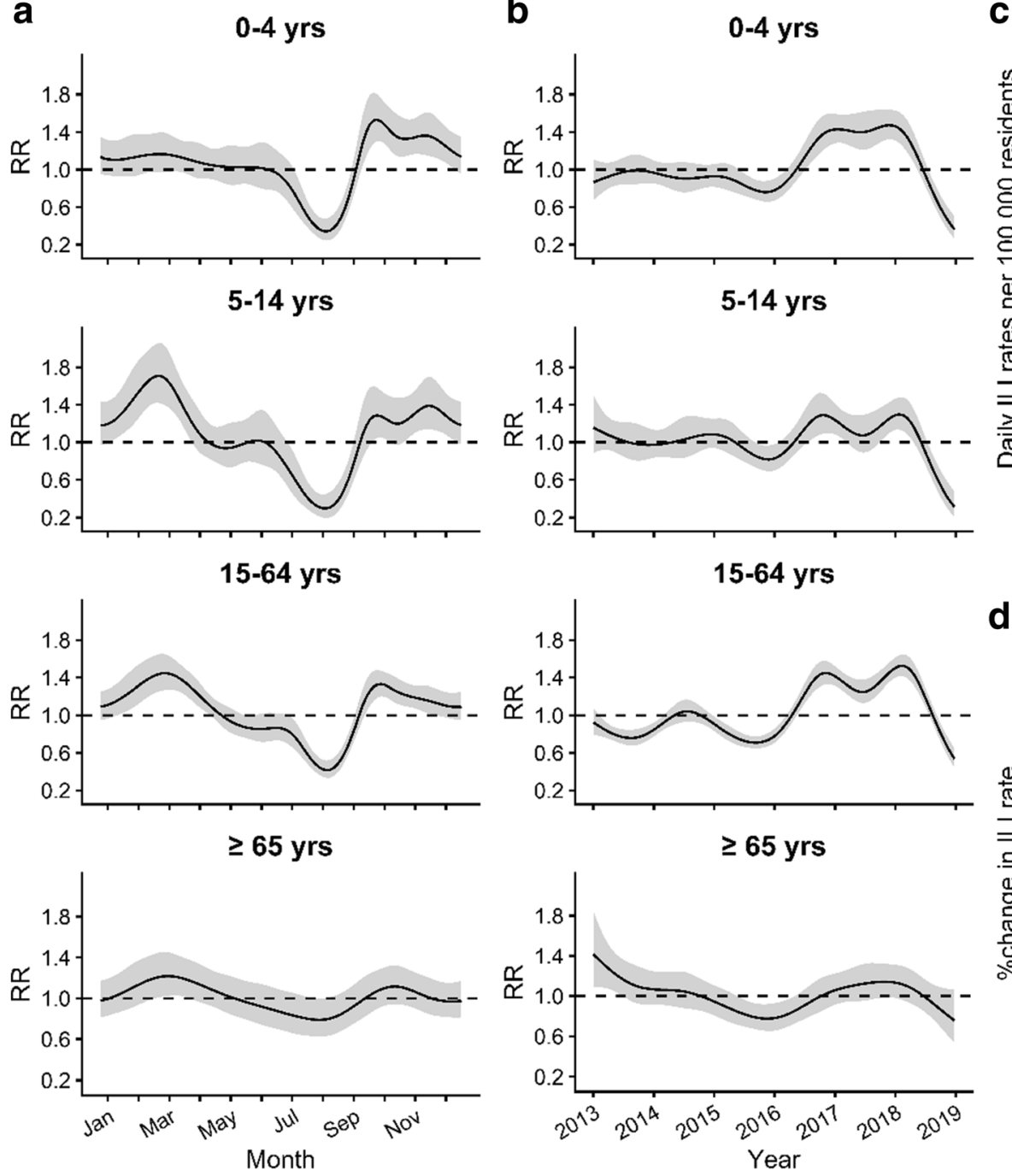

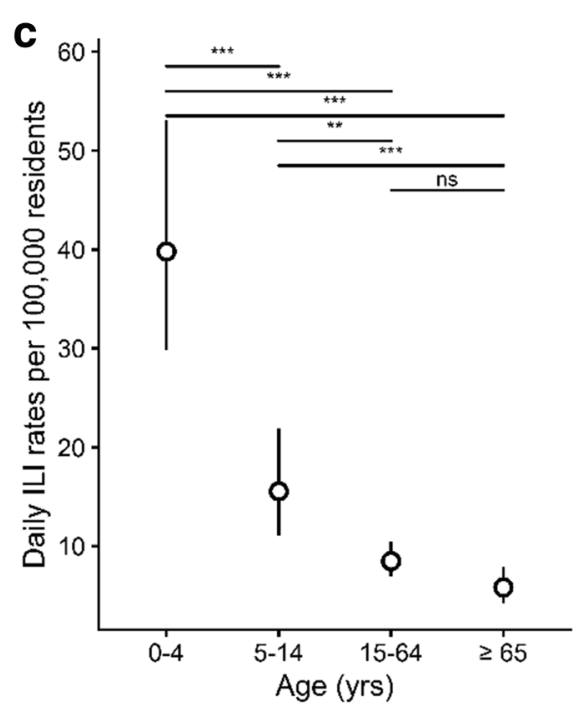

d $\$$ PM2.5 4 UTCI $\$$ PM10 $\$$ UTCI

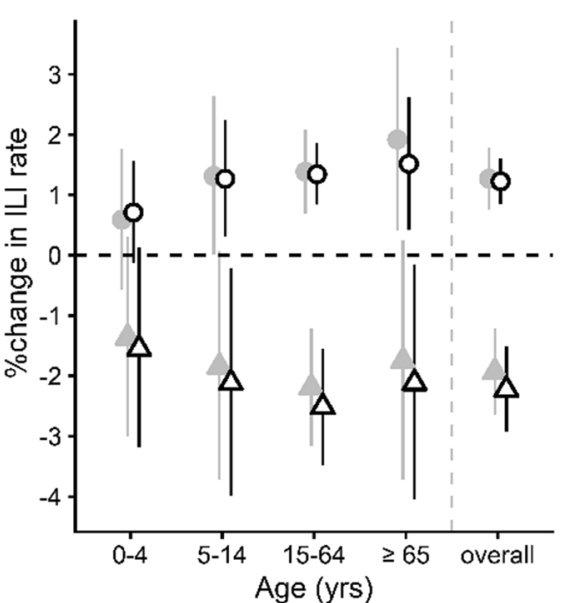

Fig. 3 Seasonal (a) and long-term trends (b) from Poisson regression fitted by GAM for the combined age group series expressed as rate ratios (RR) relative to the overall mean. Estimated marginal mean ILI rates for the age groups (c) with tests for pairwise differences (ns: $p \geq 0.05$, *: $p<0.05, * *: p<0.01, * * *: p<0.001)$ adjusted by Tukey method for

groups, and the corresponding confidence intervals were overlapping with zero, the interactions of both UTCI and PM2.5 or PM10, respectively, with age were statistically non-significant as indicated by the $p$ values of the corresponding interaction terms from likelihood ratio tests $\left(\mathrm{p}_{\text {age }} * \mathrm{UTCI}=0.84\right.$, $\mathrm{p}_{\text {age }} \mathrm{PM}_{10}=0.65$ for model with predictors UTCI and PM10; $\mathrm{p}_{\text {age } * \text { UTCI }}=0.87, \mathrm{p}_{\text {age } * \text { PM2 } 2.510}=0.55$ with predictors UTCI and PM2.5) (Wood 2006).

\section{Discussion}

Influenza outbreaks are well synchronized in time in temperate climates; however, the timing and individual characteristics of epidemics change regionally (Wenger and Naumova comparing a family of 4 estimates. Interaction of the percentage changes in ILI rates per unit increase in the predictors UTCI and PM2.5 (grey symbols), or UTCI and PM10 (black open symbols), respectively, with age together with the overall estimate from the main effects model (d). Error bands and bars indicate $95 \%$ confidence intervals

2010; Schanzer et al. 2011). Our results confirmed that in Warsaw (Poland), the highest ILI rates were observed in winter, which is typical for temperate regions (Lofgren et al. 2007). The rate of ILI incidences reported approximately weekly, recorded between 2013 and 2018, shows noticeable variation in magnitude for different years. Inter-annual variations of influenza epidemics could be partially explained by the virus type and strain that actually predominated in the population (Reichert et al. 2004). According to Bouvier and Palese (2008), influenza type A viruses are transmitted more efficiently than type B, causing higher morbidity. Due to considerable antigenic diversity of human influenza viruses, annual ILI incidence rates vary from year-to-year, being strongly affected by two concurrent mechanisms: the emergence of new influenza strains and population immunization against 
new pathogens (Truscott et al. 2012). Very low ILI trend values at the end of 2018 were presumably attributable to the closure of the majority of medical centres for Christmas, which is typical for health service in Poland. Similar limitations in access to medical services at the end of the year were observed in Greece by Nastos and Matzarakis (2006).

Numerous studies have confirmed that meteorological conditions are to some extent associated with respiratory tract infections, especially with influenza and influenza-like illnesses incidence (Lowen et al. 2007; Tamerius et al. 2011; Van Noort et al. 2012; Wang et al. 2017; Peci et al. 2019; Price et al. 2019). In our study, air temperature and vapour pressure were found to be strongly negatively correlated with ILI incidence $(-0.73)$, while the association with relative humidity was moderately positive $(0.44)$. Similar relationships were also found with ILI rates in the Republic of Korea (Park et al. 2020) and with lower respiratory tract infection hospitalization rate in China (Liu et al. 2016). Weaker, but significant correlations were reported between air temperature and hospitalization of children $<16$ years due to influenza type A and B ( -0.53 and -0.33 respectively) in Germany by du Prel et al. (2009). The impact of particular meteorological variables on morbidity can be different depending on influenza type predominating in the population (Price et al. 2019).

Climate and weather have a strong impact on ILI incidence, but examining the effects of individual meteorological factors on viral activity can lead to incomplete conclusions (Lawrence 2005), if potential interactions between these factors are not considered (Roussel et al. 2016). According to our results, daily ILI rates were strongly associated with biothermal conditions $(r=-0.72)$, determined by mean values of UTCI index in Warsaw. It is worth mentioning that combining the effect of various atmospheric variables into one measure has not been common approach in previous studies on influenza and ILI morbidity environmental conditionings, and indeed correlation was basically the same when using mean air temperature instead of UTCI. Nevertheless, UTCI considers the influence of temperature, wind, humidity, and heat radiation on human physiology, and thus, it helps overcoming methodological issues in regression analyses related to multi-collinearity between meteorological variables, especially if lagged values are considered. To our knowledge, so far, only Romaszko et al. (2019) have applied this biometeorological index in an epidemiological study and found strong inverse correlation $(-0.757)$ between weekly mean UTCI values and the number of hospital admissions for respiratory tract infections.

In our study, mean daily concentrations of PM2.5 and PM10 were moderately positively correlated with daily ILI rates ( 0.67 and 0.54 , respectively). The observed associations were stronger than those reported previously by $\mathrm{Su}$ et al. (2019) in China (for PM2.5 and PM10 $r=0.31$ ) or Park et al. (2020) in South Korea (for PM10 $r=0.38$ ). Our results support the hypothesis that air pollution, especially particulate matter, could affect airways and increase susceptibility to respiratory virus infections (Ciencewicki and Jaspers 2007). Exposure to PM containing environmentally persistent free radicals (EPFRs) can induce pulmonary oxidative stress and suppress immune response to influenza virus (Lee et al. 2014). In addition, it has been recently suggested (Asadi et al. 2020) that influenza virus can spread through the airborne dust and other microscopic particles. Thus, high PM concentrations may increase the probability to inhale these pathogens and contribute to the infection development. Some researchers also interrelate high PM concentrations with the reduction of UV radiation reaching the ground, which inhibits biological activity of solar radiation and may contribute to the spread of influenza virus as a result (Qin et al. 2012).

We demonstrated that excess ILI incidence in Warsaw increased with rising PM2.5 or PM10 concentration, and with cooling biothermal conditions, indicated by decreasing UTCI values, although the observed effect proved to be smaller for the distributed model, with UTCI being insignificant as a predictor in the particular time lags. However, the net effect of UTCI and PM on ILI rates turned out to be statistically significant and nearly identical to the averaged effect of individual models. Our findings concerning UTCI as a predictor of ILI incidence are in accordance with conclusions by Romaszko et al. (2019), regarding respiratory tract infections. In that study, a significant increase in morbidity was observed, when UTCI values dropped by two thermal load classes, particularly when cold stress appeared at the same time. Our results acknowledged that excessive cooling of the human body requires a lot of energy for thermoregulation at the expense of immune defence, which makes an organism more susceptible to viral infections (Lofgren et al. 2007; Jaakkola et al. 2014). Concurrently, we found that overall RR of PM2.5 and PM10 affecting ILI rates in both the individual and the distributed models were very similar to the results of $\mathrm{Su}$ et al. (2019) obtained from quasi-Poisson regression models for single pollutants in China. On the contrary, Liu et al. (2019) observed that PM10 was negatively associated with weekly ILI medical consultations, while relationship between PM2.5 and ILI cases was positive. Moreover, Feng et al. (2016) noticed that the effect of PM2.5 on the ILI risk increased progressively with rising air pollution only in the flu season, when hosts were more susceptible to infection due to body cooling, and became insignificant in warmer and more humid conditions. Our data, which were appropriately described by a main effects linear Poisson regression model, suggest that high levels of air pollution and low UTCI values independently add to an increased ILI incidence rate. Although we did not find a higher sensitivity to PM in the cold season as reported by Feng et al. (2016), both studies support the idea that particular matter impact on influenza morbidity should be analysed together with biothermal conditions. 
Another important finding of the present study was that PM concentration has the strongest effect on ILI incidence on the actual reporting period. Although data aggregation leads to smoothing extreme values and may result in not exact reflection of the actual exposure on the citizens, it has been previously demonstrated that weekly averaged data can be successfully used to assess influence of meteorological parameters and air pollution on ILI incidence (Huang et al. 2017; Liu et al. 2019).

In case of UTCI, there is less differentiation in the effect over the considered three periods, although the highest RR of increase in ILI was observed for 1-period lag. Regarding respiratory tract infections, previous studies confirmed that the number of daily consultations demonstrated a 7-day lag in the increased number of admissions after significant change in meteorological conditions (Romaszko et al. 2019); however, 10 and 14 days lags between worsened weather and higher morbidity were also reported (Nastos and Matzarakis 2006; Mäkinen et al. 2009).

For influenza type A incidence in Sweden, Sundell et al. (2016) found a significant association with the drop of air temperature the week before, what was in accordance with other studies on the effects of meteorological factors (i.e. air temperature and humidity) on influenza seasonality, recognizing 1-week lag between the cause and the effect (Wang et al. 2017; Park et al. 2020). However, longer incubation periods of influenza virus were also observed, e.g. 8 days in Japan (Tsuchihashi et al. 2011) and 13 days in China (Zhang et al. 2015). Likewise, recent studies confirm our results concerning short lagged effect of PM on ILI incidence. The impact of high concentration of PM2.5 and PM10 on higher ILI morbidity was limited usually up to 3 days before medical consultation (Huang et al. 2016; Su et al. 2019). Similar time lags between air pollution and increased number of medical consultations were reported for respiratory tract infections (Ostro et al. 1999; Tam et al. 2014).

In our study, the majority of ILI cases were reported among people 15-64 years, but when standardized for population size, daily ILI incidence rate showed a decreasing trend with age. The observed tendency could support the hypothesis that particularly children of $0-4$ years are susceptible to virus infections, as their immunological system is not fully mature (Valenciano et al. 2013; Feng et al. 2016). Moreover, children are considered more vulnerable to the effects of meteorological factors and air pollution, as they tend to spend more time playing outdoors (Xu et al. 2013; Li et al. 2018). Contrarily, several studies (Feng et al. 2016; Huang et al. 2016; $\mathrm{Su}$ et al. 2019) found that ILI rates could be the lowest in the youngest age group due to the fact that infants were better protected and less frequently exposed to adverse atmospheric conditions. Furthermore, ILI rates for young children in our data could possibly be overestimated, as young organisms sometimes manifest non-specific febrile illnesses or suffer from other respiratory diseases that are very difficult to distinguish from ILI (Cox and Subbarao 1999). We also observed that ILI rates in the oldest age group ( $\geq 65$ years) were the smallest and less diversified seasonally and annually. This finding is in accordance with a previous study from Australia, where the smallest effect of seasonality on influenza risk among elderly people was associated with a high vaccine uptake by this age group (Huang et al. 2017). In Poland, people aged over 65 years were the most immunized population group (Brydak et al. 2012), although the rate of influenza vaccination in the whole Polish society was in general very low comparing to other European countries (ECDC 2018). Concurrently elderly people were reported to have less social interactions than school children and working adults, which resulted in lower contact rates and could limit the spread of infection within the oldest citizens (Wallinga et al. 2006; Mossong et al. 2008). On the other hand, increased social contacts might not be the likely explanation for the higher ILI rates in young children (0-4 years), as typically in Poland, until 3 years old, they usually spend time at home with mothers or babysitters. In 2017 , only $11.6 \%$ of children under age 3 in Poland attended early childhood education and care institutions (Eurydice 2019).

In our study, ILI rates significantly declined with age, when adjusted for population size, nevertheless the effects of PM2.5 or PM10 and UTCI on daily ILI rates in Warsaw did not depend on age. Therefore, our results confirm observation of Roussel et al. (2016) that climatic factors have a uniform impact on influenza spread within the population regardless of age.

Due to the nature of ILI data collected by Polish Sanitary Inspection, our study has some limitations. First, ILI reports are anonymised, and it is impossible to determine whether individuals included in the statistics lived in the study area and were influenced by the investigated atmospheric factors or arrived from different places (Price et al. 2019). Second, as discussed above, our data was aggregated to reporting periods; thus, meteorological parameters had to be averaged accordingly, what smoothed the extremums of atmospheric conditions and reduced their possible impact on influenza morbidity. In addition, in winter, when ILI morbidity is the greatest, people spend a lot of time indoors, where biothermal conditions and air quality differ significantly from those outdoors. Therefore, standard meteorological and air pollution data may be an imperfect indicator of individual exposure to particular environmental conditions (Chan et al. 2009; Wiemken et al. 2017). Finally, as proven recently, even laboratory-infected volunteers do not regularly demonstrate all symptoms of ILI (Babcock et al. 2006; Lau et al. 2010), which may suggest that prevalence of influenza infections in the studied population could be even higher than reported ILI rates (Van Noort et al. 2012).

Nevertheless, although data aggregation leads to smoothing extreme values and may result in not exact reflection of the actual exposure on the citizens, it has been previously demonstrated that weekly averaged data can be successfully used to 
assess the influence of meteorological parameters and air pollution on ILI incidence (Huang et al. 2017; Liu et al. 2019).

\section{Conclusion}

Our results confirmed that there is a significant relationship between ILI incidence in Warsaw and biothermal conditions, as well as PM concentration after adjusting for seasonal and annual trends. We also showed that UTCI can serve as predictor not only of respiratory tract infections (Romaszko et al. 2019) in general but also of influenza-like illnesses. Nevertheless, taking into account seasonal and annual trends in such analysis is advisable, as virus activity in the population is also affected by other factors, e.g. seasonally changing host susceptibility, contact rates among people, and pathogen infectivity connected with antigenic novelty of virus strains (Lofgren et al. 2007; Van Noort et al. 2012; Li et al. 2018).

This study concerning the impact of biometeorological factors and air pollution on the morbidity due to influenza-like illnesses in Warsaw extends former research focused only on the occurrence of influenza in the whole Mazovia Voivodeship during two epidemiological seasons (Korzeniecki 2015). Better understanding environmental conditionings of influenza seasonality in temperate climate will be beneficial to forecasting future dynamics of ILI and to planning clinical and public health resources under climate change or pandemic scenarios (Watts et al. 2015).

Supplementary Information The online version contains supplementary material available at https://doi.org/10.1007/s00484-021-02076-2.

Open Access This article is licensed under a Creative Commons Attribution 4.0 International License, which permits use, sharing, adaptation, distribution and reproduction in any medium or format, as long as you give appropriate credit to the original author(s) and the source, provide a link to the Creative Commons licence, and indicate if changes were made. The images or other third party material in this article are included in the article's Creative Commons licence, unless indicated otherwise in a credit line to the material. If material is not included in the article's Creative Commons licence and your intended use is not permitted by statutory regulation or exceeds the permitted use, you will need to obtain permission directly from the copyright holder. To view a copy of this licence, visit http://creativecommons.org/licenses/by/4.0/.

\section{References}

Adamczyk J, Piwowar A, Dzikuć M (2017) Air protection programmes in Poland in the context of the low emission. Environ Sci Pollut Res Int 24:16316-16327. https://doi.org/10.1007/s11356-017-9233-9

Agrawal AS, Sarkar M, Chakrabarti S, Rajendran K, Kaur H, Mishra AC, Chatterjee MK, Naik TN, Chadha MS, Chawla-Sarkar M (2009) Comparative evaluation of real-time PCR and conventional RTPCR during a 2 year surveillance for influenza and respiratory syncytial virus among children with acute respiratory infections in Kolkata, India, reveals a distinct seasonality of infection. J Med Microbiol 58:1616-1622. https://doi.org/10.1099/jmm.0.011304-0

Armstrong BG, Gasparrini A, Tobias A, Sera F (2020) Sample size issues in time series regressions of counts on environmental exposures. BMC Med Res Methodol 20:15. https://doi.org/10.1186/s12874019-0894-6

Asadi S, Gaaloul ben Hnia N, Barre RS, Wexler AS, Ristenpart WD, Bouvier NM (2020) Influenza a virus is transmissible via aerosolized fomites. Nat Commun 11:4062. https://doi.org/10.1038/ s41467-020-17888-w

Babcock HM, Merz LR, Fraser VJ (2006) Is influenza an influenza-like illness? Clinical presentation of influenza in hospitalized patients. Infect Control Hosp Epidemiol 27:266-270. https://doi.org/10. $1086 / 501539$

Bhaskaran K, Gasparrini A, Hajat S, Smeeth L, Armstrong B (2013) Time series regression studies in environmental epidemiology. Int J Epidemiol 42:1187-1195. https://doi.org/10.1093/ije/dyt092

Błażejczyk K. (2005) MENEX_2005 - the updated version of manenvironment heat exchange model. https://www.igipz.pan.pl/tl files/igipz/ZGiK/opracowania/indywidualne/blazejczyk/MENEX_ 2005.pdf

Błażejczyk K, Jendritzky G, Bröde P, Fiala D, Havenith G, Epstein Y, Psikuta A, Kampmann B (2013) An introduction to the universal thermal climate index (UTCI). Geogr Pol 86(1):5-10. https://doi. org/10.7163/GPol.2013.1

Błażejczyk K, Kuchcik M, Blażejczyk A, Milewski P, Szmyd J (2014) Assessment of urban thermal stress by UTCI - experimental and modelling studies: an example from Poland. Erde 145(1-2):16-33 . https://doi.org/10.12854/erde-145-3

Bouvier NM, Palese P (2008) The biology of influenza viruses. Vaccine 26:D49-D53. https://doi.org/10.1016/j.vaccine.2008.07.039

Brankston G, Gitterman L, Hirji Z, Lemieux C, Gardam M (2007) Transmission of influenza a in human beings. Lancet Infect Dis 7: 257-265. https://doi.org/10.1016/S1473-3099(07)70029-4

Brydak LB, Woźniak Kosek A, Nitsch-Osuch A (2012) Influenza vaccines and vaccinations in Poland - past, present and future. Med Sci Monit 18: RA166-RA171 . https://doi.org/10.12659/msm.883534

Buckingham-Jeffery E, Morbey R, House T, Elliot AJ, Harcourt S, Smith GE (2017) Correcting for day of the week and public holiday effects: improving a national daily syndromic surveillance service for detecting public health threats. BMC Public Health 17:477. https://doi. org/10.1186/s12889-017-4372-y

Cannell JJ, Vieth R, Umhau JC, Holick MF, Grant WB, Madronich S, Garland CF, Giovannucci E (2006) Epidemic influenza and vitamin D. Epidemiol Infect 134:1129-1140. https://doi.org/10.1017/ S0950268806007175

Chan PW, Chew FT, Tan TN, Chua KB, Hooi PS (2002) Seasonal variation in respiratory syncytial virus chest infection in the tropics. Pediatr Pulmonol 34:47-51. https://doi.org/10.1002/ppul.10095

Chan PKS, Mok HY, Lee TC, Chu IMT, Lam W-Y, Sung JJY (2009) Seasonal influenza activity in Hong Kong and its association with meteorological variations. J Med Virol 81:1797-1806. https://doi. org/10.1002/jmv.21551

Chen G, Zhang W, Li S, Zhang Y, Williams G, Huxley R, Ren H, Cao W, Guo Y (2017) The impact of ambient fine particles on influenza transmission and the modification effects of temperature in China: a multi-city study. Environ Int 98:82-88. https://doi.org/10.1016/J. ENVINT.2016.10.004

Ciencewicki J, Jaspers I (2007) Air pollution and respiratory viral infection. Inhal Toxicol 19:1135-1146. https://doi.org/10.1080/ 08958370701665434

R Core Team (2020) R: a language and environment for statistical computing. In: R A Lang. Environ. Stat. Comput. https://www.r-project. org/. Accessed 12 Apr 2020 
Cox NJ, Subbarao K (1999) Influenza. Lancet (London, England) 354: 1277-82. https://doi.org/10.1016/S0140-6736(99)01241-6

Cox NJ, Subbarao K (2000) Global epidemiology of influenza: past and present. Annu Rev Med 51:407-421. https://doi.org/10.1146/ annurev.med.51.1.407

Crépey P, Barthélemy M (2007) Detecting robust patterns in the spread of epidemics: a case study of influenza in the United States and France. Am J Epidemiol 166:1244-1251. https://doi.org/10.1093/aje/ kwm266

de Arruda NE, Hayden FG, McAuliffe JF, Auxiliadora de Sousa M, Mota SB, McAuliffe MI, Geist FC, Carvalho EP, Fernandes MC, Guerrant RL, Gwaltney JM (1991) Acute respiratory viral infections in ambulatory children of urban Northeast Brazil. J Infect Dis 164: 252-258. https://doi.org/10.1093/infdis/164.2.252

Department of Infectious Disease Epidemiology and Surveillance NIZPPZH (2019) Definitions of infectious disease cases for the needs of epidemiological surveillance, 2018. Warsaw

Dowell SF (2001) Seasonal variation in host susceptibility and cycles of certain infectious diseases. Emerg Infect Dis 7:369-374. https://doi. org/10.3201/eid0703.017301

du Prel J, Puppe W, Gröndahl B, Knuf M, Weigl JAI, Schaaff F, Schmitt H (2009) Are meteorological parameters associated with acute respiratory tract infections? Clin Infect Dis 49:861-868. https://doi. org $/ 10.1086 / 605435$

Dunn PK, Smyth GK (2018) Chapter 6: generalized linear models: estimation. In: Generalized linear models with examples in R. Springer New York, New York, NY, pp 243-263

Eccles R (2002) An explanation for the seasonality of acute upper respiratory tract viral infections. Acta Otolaryngol 122:183-191. https:// doi.org/10.1080/00016480252814207

Eccles R (2005) Understanding the symptoms of the common cold and influenza. Lancet Infect Dis 5:718-725. https://doi.org/10.1016/ S1473-3099(05)70270-X

ECDC (2018) Seasonal influenza vaccination and antiviral use in EU/ EEA member states. Stockholm

Eurydice (2019) Key data on early childhood education and care in Europe - 2019 Edition. Eurydice Report. Publications Office of the European Union, Luxembourg. https://doi.org/10.2797/894279

Fasiolo M, Nedellec R, Goude Y, Wood SN (2020) Scalable visualization methods for modern generalized additive models. J Comput Graph Stat 29:78-86. https://doi.org/10.1080/10618600.2019.1629942

Fdez-Arroyabe P (2012) Influenza epidemics and Spanish climatic domains. Health (Irvine Calif) 04:941-945. https://doi.org/10.4236/ health.2012.430144

Feng C, Li J, Sun W, Zhang Y, Wang Q (2016) Impact of ambient fine particulate matter (PM2.5) exposure on the risk of influenza-likeillness: a time-series analysis in Beijing, China. Environ Heal A Glob Access Sci Source 15:1-13. https://doi.org/10.1186/s12940016-0115-2

Finkelman BS, Viboud C, Koelle K, Ferrari MJ, Bharti N, Grenfell BT (2007) Global patterns in seasonal activity of influenza a/H3N2, a/H1N1, and B from 1997 to 2005: viral coexistence and latitudinal gradients. PLoS One 2:e1296. https://doi.org/10.1371/journal.pone. 0001296

Fisman D (2012) Seasonality of viral infections: mechanisms and unknowns. Clin Microbiol Infect 18:946-954. https://doi.org/10. 1111/j.1469-0691.2012.03968.x

Fuhrmann C (2010) The effects of weather and climate on the seasonality of influenza: what we know and what we need to know. Geogr Compass 4:718-730. https://doi.org/10.1111/j.1749-8198.2010. 00343.x

Ginde AA, Mansbach JM, Camargo CA (2009) Association between serum 25-hydroxyvitamin D level and upper respiratory tract infection in the third National Health and nutrition examination survey. Arch Intern Med 169:384-390. https://doi.org/10.1001/ archinternmed.2008.560
Gomez-Barroso D, León-Gómez I, Delgado-Sanz C, Larrauri A (2017) Climatic factors and influenza transmission, Spain, 2010-2015. Int J Environ Res Public Health 14:1469. https://doi.org/10.3390/ ijerph14121469

Gustin KM, Belser JA, Veguilla V, Zeng H, Katz JM, Tumpey TM, Maines TR (2015) Environmental conditions affect exhalation of $\mathrm{H} 3 \mathrm{~N} 2$ seasonal and variant influenza viruses and respiratory droplet transmission in ferrets. PLoS One 10:1-19. https://doi.org/10.1371/ journal.pone. 0125874

Hammond GW, Raddatz RL, Gelskey DE (1989) Impact of atmospheric dispersion and transport of viral aerosols on the epidemiology of influenza. Rev Infect Dis 11:494-497. https://doi.org/10.1093/ clinids/11.3.494

Heikkinen T, Järvinen A (2003) The common cold. Lancet 361:51-59. https://doi.org/10.1016/S0140-6736(03)12162-9

Huang L, Zhou L, Chen J, Chen K, Liu Y, Chen X, Tang F (2016) Acute effects of air pollution on influenza-like illness in Nanjing, China: a population-based study. Chemosphere 147:180-187. https://doi. org/10.1016/j.chemosphere.2015.12.082

Huang X, Mengersen K, Milinovich G, Hu W (2017) Effect of weather variability on seasonal influenza among different age groups in Queensland, Australia: a Bayesian spatiotemporal analysis. J Infect Dis 215:1695-1701. https://doi.org/10.1093/infdis/jix181

Huppert A, Barnea O, Katriel G, Yaari R, Roll U, Stone L (2012) Modeling and statistical analysis of the spatio-temporal patterns of seasonal influenza in Israel. PLoS One 7:e45107. https://doi.org/10. 1371/journal.pone.0045107

Hwang J-S, Chan C-C (2002) Effects of air pollution on daily clinic visits for lower respiratory tract illness. Am J Epidemiol 155:1-10. https:// doi.org/10.1093/aje/155.1.1

Iha Y, Kinjo T, Parrott G, Higa F, Mori H, Fujita J (2016) Comparative epidemiology of influenza a and B viral infection in a subtropical region: a 7-year surveillance in Okinawa, Japan. BMC Infect Dis 16: 650. https://doi.org/10.1186/s12879-016-1978-0

Institute of Meteorology and Water Management (2020) Institute of Meteorology and Water Management

Iuliano AD, Roguski KM, Chang HH, Muscatello DJ, Palekar R, Tempia S, Cohen C, Gran JM, Schanzer D, Cowling BJ, Wu P, Kyncl J, Ang LW, Park M, Redlberger-Fritz M, Yu H, Espenhain L, Krishnan A, Emukule G, van Asten L, Pereira da Silva S, Aungkulanon S, Buchholz U, Widdowson M-A, Bresee JS, Azziz-Baumgartner E, Cheng P-Y, Dawood F, Foppa I, Olsen S, Haber M, Jeffers C, MacIntyre CR, Newall AT, Wood JG, Kundi M, Popow-Kraupp T, Ahmed M, Rahman M, Marinho F, Sotomayor Proschle CV, Vergara Mallegas N, Luzhao F, Sa L, Barbosa-Ramírez J, Sanchez DM, Gomez LA, Vargas XB, Acosta Herrera aB, Llanés MJ, Fischer TK, Krause TG, Mølbak K, Nielsen J, Trebbien R, Bruno A, Ojeda J, Ramos H, van der Heiden M, del Carmen Castillo Signor L, Serrano CE, Bhardwaj R, Chadha M, Narayan V, Kosen S, Bromberg M, Glatman-Freedman A, Kaufman Z, Arima Y, Oishi K, Chaves S, Nyawanda B, Al-Jarallah RA, Kuri-Morales PA, Matus CR, MEJ C, Burmaa A, Darmaa O, Obtel M, Cherkaoui I, van den Wijngaard CC, van der Hoek W, Baker M, Bandaranayake D, Bissielo A, Huang S, Lopez L, Newbern C, Flem E, Grøneng GM, Hauge S, de Cosío FG, de Moltó Y, Castillo LM, Cabello MA, von Horoch M, Medina Osis J, Machado A, Nunes B, Rodrigues AP, Rodrigues E, Calomfirescu C, Lupulescu E, Popescu R, Popovici O, Bogdanovic D, Kostic M, Lazarevic K, Milosevic Z, Tiodorovic B, Chen M, Cutter J, Lee V, Lin R, Ma S, Cohen AL, Treurnicht F, Kim WJ, Delgado-Sanz C, De Mateo Ontañón S, Larrauri A, León IL, Vallejo F, Born R, Junker C, Koch D, Chuang J-H, Huang W-T, Kuo H-W, Tsai Y-C, Bundhamcharoen K, Chittaganpitch M, Green HK, Pebody R, Goñi N, Chiparelli H, Brammer L, Mustaquim D (2018) Estimates of global seasonal influenza-associated respiratory mortality: a modelling study. 
Lancet 391:1285-1300. https://doi.org/10.1016/S0140-6736(17) 33293-2

Jaakkola K, Saukkoriipi A, Jokelainen J, Juvonen R, Kauppila J, Vainio O, Ziegler T, Rönkkö E, JJK J, Ikäheimo TM, Group the K-S (2014) Decline in temperature and humidity increases the occurrence of influenza in cold climate. Environ Health 13:22. https://doi.org/10. 1186/1476-069X-13-22

Jaspers I, Ciencewicki JM, Zhang W, Brighton LE, Carson JL, Beck MA, Madden MC (2005) Diesel exhaust enhances influenza virus infections in respiratory epithelial cells. Toxicol Sci 85:990-1002. https:// doi.org/10.1093/toxsci/kfil41

Jensen MM (1964) Inactivation of airborne viruses by ultraviolet irradiation. Appl Microbiol 12:418-420. https://doi.org/10.1128/aem.12. $5.418-420.1964$

Korzeniecki P (2015) Warunki pogodowe sprzyjające zwiększonej zachorowalności na grypę w województwie mazowieckim (Weather conditions associated with increased occurrence of influenza in the Mazovia Voivodeship in Poland). In: Liro J., Liro M. KP (ed) Współczesne problemy i kierunki badawcze w geografii Tom 3. Instytut geografii i gospodarki przestrzennej UJ, pp 109-122

Lau LLH, Cowling BJ, Fang VJ, Chan K-H, Lau EHY, Lipsitch M, Cheng CKY, Houck PM, Uyeki TM, Peiris JSM, Leung GM (2010) Viral shedding and clinical illness in naturally acquired influenza virus infections. J Infect Dis 201:1509-1516. https://doi.org/ $10.1086 / 652241$

Lawrence MG (2005) The relationship between relative humidity and the dewpoint temperature in moist air: a simple conversion and applications. Bull Am Meteorol Soc 86:225-234. https://doi.org/10.1175/ BAMS-86-2-225

Lee GI, Saravia J, You D, Shrestha B, Jaligama S, Hebert VY, Dugas TR, Cormier SA (2014) Exposure to combustion generated environmentally persistent free radicals enhances severity of influenza virus infection. Part Fibre Toxicol 11:57. https://doi.org/10.1186/ s12989-014-0057-1

Lenth R (2020) Emmeans: estimated marginal means, aka least-squares means. In: emmeans Estim. Marg. Means, aka Least-Squares Means

Li Y, Wang XL, Zheng X (2018) Impact of weather factors on influenza hospitalization across different age groups in subtropical Hong Kong. Int J Biometeorol 62:1615-1624. https://doi.org/10.1007/ s00484-018-1561-z

Lipsitch M, Viboud C (2009) Influenza seasonality: lifting the fog. Proc Natl Acad Sci U S A 106:3645-3646

Liu Y, Liu J, Chen F, Shamsi BH, Wang Q, Jiao F, Qiao Y, Shi Y (2016) Impact of meteorological factors on lower respiratory tract infections in children. J Int Med Res 44:30-41. https://doi.org/10.1177/ 0300060515586007

Liu XX, Li Y, Qin G, Zhu Y, Li X, Zhang J, Zhao K, Hu M, Wang XL, Zheng X (2019) Effects of air pollutants on occurrences of influenza-like illness and laboratory-confirmed influenza in Hefei, China. Int J Biometeorol 63:51-60. https://doi.org/10.1007/s00484018-1633-0

Lochmiller RL, Deerenberg C (2000) Trade-offs in evolutionary immunology: just what is the cost of immunity? Oikos 88:87-98. https:// doi.org/10.1034/j.1600-0706.2000.880110.x

Lofgren E, Fefferman NH, Naumov YN, Gorski J, Naumova EN (2007) Influenza seasonality: underlying causes and modeling theories. J Virol 81:5429-5436. https://doi.org/10.1128/jvi.01680-06

Lowen AC, Steel J (2014) Roles of humidity and temperature in shaping influenza seasonality. J Virol 88:7692-7695. https://doi.org/10. 1128/jvi.03544-13

Lowen AC, Mubareka S, Steel J, Palese P (2007) Influenza virus transmission is dependent on relative humidity and temperature. PLoS Pathog 3:1470-1476. https://doi.org/10.1371/journal.ppat.0030151

Lowen AC, Steel J, Mubareka S, Palese P (2008) High temperature $\left(30^{\circ} \mathrm{C}\right)$ blocks aerosol but not contact transmission of influenza virus. J Virol 82:5650-5652. https://doi.org/10.1128/jvi.00325-08
Mäkinen TM, Juvonen R, Jokelainen J, Harju TH, Peitso A, Bloigu A, Silvennoinen-Kassinen S, Leinonen M, Hassi J (2009) Cold temperature and low humidity are associated with increased occurrence of respiratory tract infections. Respir Med 103:456-462. https://doi. org/10.1016/j.rmed.2008.09.011

Mandl KD, Overhage JM, Wagner MM, Lober WB, Sebastiani P, Mostashari F, Pavlin JA, Gesteland PH, Treadwell T, Koski E, Hutwagner L, Buckeridge DL, Aller RD, Grannis S (2004) Implementing syndromic surveillance: a practical guide informed by the early experience. J Am Med Inform Assoc 11:141-150. https://doi.org/10.1197/jamia.M1356

Martineau AR, Jolliffe DA, Hooper RL, Greenberg L, Aloia JF, Bergman P, Dubnov-Raz G, Esposito S, Ganmaa D, Ginde AA, Goodall EC, Grant CC, Griffiths CJ, Janssens W, Laaksi I, Manaseki-Holland S, Mauger D, Murdoch DR, Neale R, Rees JR, Simpson S, Stelmach I, Kumar GT, Urashima M, Camargo CA (2017) Vitamin D supplementation to prevent acute respiratory tract infections: systematic review and meta-analysis of individual participant data. BMJ 356: i6583. https://doi.org/10.1136/bmj.i6583

McDevitt J, Rudnick S, First M, Spengler J (2010) Role of absolute humidity in the inactivation of influenza viruses on stainless steel surfaces at elevated temperatures. Appl Environ Microbiol 76: 3943-3947. https://doi.org/10.1128/AEM.02674-09

Meerhoff TJ, Paget WJ, Aguilera JF, van der Velden J (2004) Harmonising the virological surveillance of influenza in Europe: results of an 18-country survey. Virus Res 103:31-33. https://doi. org/10.1016/j.virusres.2004.02.009

Minh An DT, Ngoc NTB, Nilsson M (2014) Influenza-like illness in a Vietnamese province: epidemiology in correlation with weather factors and determinants from the surveillance system. Glob Health Action 7:1-14. https://doi.org/10.3402/gha.v7.23073

Moorthy M, Castronovo D, Abraham A, Bhattacharyya S, Gradus S, Gorski J, Naumov YN, Fefferman NH, Naumova EN (2012) Deviations in influenza seasonality: odd coincidence or obscure consequence? Clin Microbiol Infect 18:955-962. https://doi.org/ 10.1111/j.1469-0691.2012.03959.x

Mossong J, Hens N, Jit M, Beutels P, Auranen K, Mikolajczyk R, Massari M, Salmaso S, Tomba GS, Wallinga J, Heijne J, Sadkowska-Todys M, Rosinska M, Edmunds WJ (2008) Social contacts and mixing patterns relevant to the spread of infectious diseases. PLoS Med 5:e74. https://doi.org/10.1371/journal.pmed. 0050074

Moura FEA, Perdigão ACB, Siqueira MM (2009) Seasonality of influenza in the tropics: a distinct pattern in Northeastern Brazil. Am J Trop Med Hyg 81:180-183. https://doi.org/10.4269/ajtmh.2009.81. 180

Mourtzoukou EG, Falagas ME (2007) Exposure to cold and respiratory tract infections. Int J Tuberc Lung Dis 11:938-943

Nastos PT, Matzarakis A (2006) Weather impacts on respiratory infections in Athens, Greece. Int J Biometeorol 50:358-369. https://doi. org/10.1007/s00484-006-0031-1

National Research Council (2001) Under the weather. National Academies Press, Washington, D.C.

Nelson MI, Holmes EC (2007) The evolution of epidemic influenza. Nat Rev Genet 8:196-205. https://doi.org/10.1038/nrg2053

Ostro BD, Eskeland GS, Sanchez JM, Feyzioglu T (1999) Air pollution and health effects: a study of medical visits among children in Santiago, Chile. Environ Health Perspect 107:69-73. https://doi. org/10.1289/ehp.9910769

Park J-E, Son W-S, Ryu Y, Choi SB, Kwon O, Ahn I (2020) Effects of temperature, humidity, and diurnal temperature range on influenza incidence in a temperate region. Influenza Other Respir Viruses 14: 11-18. https://doi.org/10.1111/irv.12682

Peci A, Winter AL, Li Y, Gnaneshan S, Liu J, Mubareka S, Gubbay JB, Humidity A, Humidity R (2019) Effects of absolute humidity, relative humidity, temperature, and wind speed on influenza activity in 
Toronto, Ontario, Canada. Appl Environ Microbiol 85:1-13. https:// doi.org/10.1128/AEM.02426-18

Peel MC, Finlayson BL, McMahon TA (2007) Updated world map of the Köppen-Geiger climate classification. Hydrol Earth Syst Sci 11: 1633-1644. https://doi.org/10.5194/hess-11-1633-2007

Petrova VN, Russell CA (2018) The evolution of seasonal influenza viruses. Nat Rev Microbiol 16:47-60

Pica N, Bouvier NM (2012) Environmental factors affecting the transmission of respiratory viruses. Curr Opin Virol 2:90-95. https://doi. org/10.1016/j.coviro.2011.12.003

Polozov IV, Bezrukov L, Gawrisch K, Zimmerberg J (2008) Progressive ordering with decreasing temperature of the phospholipids of influenza virus. Nat Chem Biol 4:248-255. https://doi.org/10.1038/ nchembio. 77

Price RHM, Graham C, Ramalingam S (2019) Association between viral seasonality and meteorological factors. Sci Rep 9:1-11. https://doi. org/10.1038/s41598-018-37481-y

Qin J, Fang H, Chen Z, Zhai H, Zhang L, Chen X (2012) Impacts of atmospheric conditions on influenza in southern China. Part I. Taking Shenzhen City for Example. Open J Air Pollut 1:59-66 . https://doi.org/10.4236/ojap.2012.13008

Reichert TA, Simonsen L, Sharma A, Pardo SA, Fedson DS, Miller MA (2004) Influenza and the Winter increase in mortality in the United States, 1959-1999. Am J Epidemiol 160:492-502. https://doi.org/ 10.1093/aje/kwh227

Robertson SE, Roca A, Alonso P, Simoes EAF, Kartasasmita CB, Olaleye DO, Odaibo GN, Collinson M, Venter M, Zhu Y, Wright PF (2004) Respiratory syncytial virus infection: denominator-based studies in Indonesia, Mozambique, Nigeria and South Africa. Bull World Health Organ 82:914-922 . /S0042-96862004001200007

Romaszko J, Skutecki R, Bocheński M, Cymes I, Dragańska E, Jastrzębski P, Morocka-Tralle I, Jalali R, Jeznach-Steinhagen A, Glińska-Lewczuk K (2019) Applicability of the universal thermal climate index for predicting the outbreaks of respiratory tract infections: a mathematical modeling approach. Int J Biometeorol 63: 1231-1241. https://doi.org/10.1007/s00484-019-01740-y

Roussel M, Pontier D, Cohen JM, Lina B, Fouchet D (2016) Quantifying the role of weather on seasonal influenza. BMC Public Health 16:114. https://doi.org/10.1186/s12889-016-3114-x

Ruf BR, Knuf M (2014) The burden of seasonal and pandemic influenza in infants and children. Eur J Pediatr 173:265-276. https://doi.org/ 10.1007/s00431-013-2023-6

Sagripanti J-L, Lytle CD (2007) Inactivation of influenza virus by solar radiation. Photochem Photobiol 83:1278-1282. https://doi.org/10. 1111/j.1751-1097.2007.00177.x

Salah B, Dinh Xuan AT, Fouilladieu JL, Lockhart A, Regnard J (1988) Nasal mucociliary transport in healthy subjects is slower when breathing dry air. Eur Respir J 1:846-849

Schaffer FL, Soergel ME, Straube DC (1976) Survival of airborne influenza virus: effects of propagating host, relative humidity, and composition of spray fluids. Arch Virol 51:263-273. https://doi.org/10. 1007/BF01317930

Schanzer DL, Langley JM, Dummer T, Aziz S (2011) The geographic synchrony of seasonal influenza: a waves across Canada and the United States. PLoS One 6:e21471. https://doi.org/10.1371/ journal.pone. 0021471

Schulman JL, Kilbourne ED (1963) Experimental transmission of influenza virus infection in mice. II Some factors affecting the incidence of transmitted infection J Exp Med 118:267-275 . https://doi.org/10. 1084/jem.118.2.267

Shaman J, Kohn M (2009) Absolute humidity modulates influenza survival, transmission, and seasonality. Proc Natl Acad Sci U S A 106: 3243-3248. https://doi.org/10.1073/pnas.0806852106

Shaman J, Pitzer VE, Viboud C, Grenfell BT, Lipsitch M (2010) Absolute humidity and the seasonal onset of influenza in the continental United States. PLoS Biol 8:e1000316. https://doi.org/ 10.1371/journal.pbio.1000316

Shaw Stewart PD (2016) Seasonality and selective trends in viral acute respiratory tract infections. Med Hypotheses 86:104-119. https:// doi.org/10.1016/j.mehy.2015.11.005

Shoji M, Katayama K, Sano K (2011) Absolute humidity as a deterministic factor affecting seasonal influenza epidemics in Japan. Tohoku J Exp Med 224:251-256. https://doi.org/10.1620/tjem.224.251

Silva DR, Viana VP, Müller AM, Livi FP, de Dalcin PTR (2014) Respiratory viral infections and effects of meteorological parameters and air pollution in adults with respiratory symptoms admitted to the emergency room. Influenza Other Respir Viruses 8:42-52. https:// doi.org/10.1111/irv.12158

Simonsen L (1999) The global impact of influenza on morbidity and mortality. Vaccine 17:S3-S10. https://doi.org/10.1016/S0264410X(99)00099-7

Statistics Poland (2020) Statistics Poland. https://bdl.stat.gov.pl/BDL/ start. Accessed 4 Mar 2020

Su W, Wu X, Geng X, Zhao X, Liu Q, Liu T (2019) The short-term effects of air pollutants on influenza-like illness in Jinan, China. BMC Public Health 19:1-12. https://doi.org/10.1186/s12889-019$7607-2$

Sundell N, Andersson LM, Brittain-Long R, Lindh M, Westin J (2016) A four year seasonal survey of the relationship between outdoor climate and epidemiology of viral respiratory tract infections in a temperate climate. J Clin Virol 84:59-63. https://doi.org/10.1016/j.jcv. 2016.10.005

Tam WWS, Wong TW, Ng L, Wong SYS, Kung KKL, Wong AHS (2014) Association between air pollution and general outpatient clinic consultations for upper respiratory tract infections in Hong Kong. PLoS One 9:e86913. https://doi.org/10.1371/journal.pone. 0086913

Tamerius J, Nelson MI, Zhou SZ, Viboud C, Miller MA, Alonso WJ (2011) Global influenza seasonality: reconciling patterns across temperate and tropical regions. Environ Health Perspect 119:439 445. https://doi.org/10.1289/ehp.1002383

Tang JW, Lai FYL, Nymadawa P, Deng Y-M, Ratnamohan M, Petric M, Loh TP, Tee NWS, Dwyer DE, Barr IG, Wong FYW (2010) Comparison of the incidence of influenza in relation to climate factors during 2000-2007 in five countries. J Med Virol 82:19581965. https://doi.org/10.1002/jmv.21892

Tellier R (2006) Review of aerosol transmission of influenza a virus. Emerg Infect Dis 12:1657-1662. https://doi.org/10.3201/eid1211. 060426

Truscott J, Fraser C, Cauchemez S, Meeyai A, Hinsley W, Donnelly CA, Ghani A, Ferguson N (2012) Essential epidemiological mechanisms underpinning the transmission dynamics of seasonal influenza. J R Soc Interface 9:304-312. https://doi.org/10.1098/rsif.2011.0309

Tsuchihashi Y, Yorifujr T, Takao S, Suzuki E, Mori S, Doi H, Tsuda T (2011) Environmental factors and seasonal influenza onset in Okayama City, Japan: Case-crossover study. Acta Med Okayama 65:97-103 . https://doi.org/10.18926/AMO/45268

Urashima M, Segawa T, Okazaki M, Kurihara M, Wada Y, Ida H (2010) Randomized trial of vitamin D supplementation to prevent seasonal influenza a in schoolchildren. Am J Clin Nutr 91:1255-1260. https://doi.org/10.3945/ajen.2009.29094

Valenciano M, Kissling E, case-control study team C (2013) Early estimates of seasonal influenza vaccine effectiveness in Europe: results from the I-MOVE multicentre case-control study, 2012/13. Eurosurveillance 18:3. https://doi.org/10.2807/ese.18.07.20400-en

Van Noort SP, Águas R, Ballesteros S, Gomes MGM (2012) The role of weather on the relation between influenza and influenza-like illness. J Theor Biol 298:131-137. https://doi.org/10.1016/j.jtbi.2011.12. 020

Wallinga J, Teunis P, Kretzschmar M (2006) Using data on social contacts to estimate age-specific transmission parameters for 
respiratory-spread infectious agents. Am J Epidemiol 164:936-944. https://doi.org/10.1093/aje/kwj317

Wang XL, Yang L, He DH, Chiu AP, Chan KH, Chan KP, Zhou M, Wong CM, Guo Q, Hu W (2017) Different responses of influenza epidemic to weather factors among Shanghai, Hong Kong, and British Columbia. Int J Biometeorol 61:1043-1053. https://doi.org/ 10.1007/s00484-016-1284-y

Watts N, Adger WN, Agnolucci P, Blackstock J, Byass P, Cai W, Chaytor S, Colbourn T, Collins M, Cooper A, Cox PM, Depledge J, Drummond P, Ekins P, Galaz V, Grace D, Graham H, Grubb M, Haines A, Hamilton I, Hunter A, Jiang X, Li M, Kelman I, Liang L, Lott M, Lowe R, Luo Y, Mace G, Maslin M, Nilsson M, Oreszczyn T, Pye S, Quinn T, Svensdotter M, Venevsky S, Warner K, Xu B, Yang J, Yin Y, Yu C, Zhang Q, Gong P, Montgomery H, Costello A (2015) Health and climate change: policy responses to protect public health. Lancet 386:1861-1914. https://doi.org/10.1016/S01406736(15)60854-6

Weber TP, Stilianakis NI (2008) Inactivation of influenza a viruses in the environment and modes of transmission: a critical review. J Inf Secur 57:361-373. https://doi.org/10.1016/j.jinf.2008.08.013

Weinstein RA, Bridges CB, Kuehnert MJ, Hall CB (2003) Transmission of influenza: implications for control in health care settings. Clin Infect Dis 37:1094-1101. https://doi.org/10.1086/378292

Wenger JB, Naumova EN (2010) Seasonal synchronization of influenza in the United States older adult population. PLoS One 5:e10187. https://doi.org/10.1371/journal.pone.0010187

WHO (2020) No Title. http://www.euro.who.int/en/health-topics/ communicable-diseases/influenza/data-and-statistics/virology-ofhuman-influenza. Accessed 10 Feb 2020

Wiemken TL, Mattingly WA, Furmanek SP, Guinn BE, English CL, Carrico RM, Peyrani P, Ramirez JA (2017) Impact of temperature relative humidity and absolute humidity on the incidence of hospitalizations for lower respiratory tract infections due to influenza, rjinovirus, and respiratory syncytial virus: results from community-axquired pneumonia organization. Univ Louisv $\mathbf{J}$ Respir Infect 1:27-35 . https://doi.org/10.18297/jri/vol1/iss3/7

Wood S (2006) Generalized additive models: An introduction with R. Taylor \& Francis

Xiao H, Tian H, Lin X, Gao L, Dai X, Zhang X, Chen B, Zhao J, Xu J (2013) Influence of extreme weather and meteorological anomalies on outbreaks of influenza A (H1N1). Chin Sci Bull 58:741-749. https://doi.org/10.1007/s11434-012-5571-7

Xu Z, Hu W, Williams G, Clements ACA, Kan H, Tong S (2013) Air pollution, temperature and pediatric influenza in Brisbane, Australia. Environ Int 59:384-388. https://doi.org/10.1016/j.envint.2013.06. 022

Yaari R, Katriel G, Huppert A, Axelsen JB, Stone L (2013) Modelling seasonal influenza: The role of weather and punctuated antigenic drift. J R Soc Interface 10: . https://doi.org/10.1098/rsif.2013.0298

Zambon M, Stockton J, Clewley J, Fleming D (2001) Contribution of influenza and respiratory syncytial virus to community cases of influenza-like illness: an observational study. Lancet 358:1410 1416. https://doi.org/10.1016/S0140-6736(01)06528-X

Zhang Y, Feng C, Ma C, Yang P, Tang S, Lau A, Sun W, Wang Q (2015) The impact of temperature and humidity measures on influenza a (H7N9) outbreaks-evidence from China. Int J Infect Dis 30:122124. https://doi.org/10.1016/j.ijid.2014.11.010

Publisher's note Springer Nature remains neutral with regard to jurisdictional claims in published maps and institutional affiliations. 